\title{
ŻEŃSKI KLUB INTELIGENCJI CHRZEŚCIJAŃSKIEJ NA RZYMSKIM AWENTYNIE IV WIEKU
}

Poslannictwo milości przekazane przez Chrystusa i wprowadzane w życie w pierwotnych wspólnotach chrześcijańskich znalazło również odbicie w Rzymie - centrum świata starożytnego. Dobra Nowina zaczęła stopniowo ogarniać coraz szersze kręgi społeczne, nie omijając sfer arystokratycznych. Szczególną rolę odegrały tu kobiety żyjące w 2. pol IV wieku na rzymskim Awentynie, które zbierały się, by wspólnie poszerzać wiedzę religijną, szczególnie biblijną, oraz praktykować cnoty ewangeliczne. Tę grupę patrycjuszek z powodzeniem można nazwać, używając współczesnego języka, żeńskim klubem inteligencji chrześcijańskiej. Głównym, a często jedynym źródłem informacji na temat ich działalności są listy św. Hieronima. Z nich wlaśnie dowiadujemy się, iż ten nieformalny klub tworzyły: Marcela i jej matka Albina, Asela, Melania, Fabiola, Sofronia, Furia, Pryncypia, Lea, Paula wraz z córkami - Blezylą, Eustochium, Rufiną i Pauliną, a także synową Letą - żoną Toksocjusza, Felicyta ${ }^{1}$,

${ }^{1}$ Por. Epistula 45 (do Aseli), 7, PL 22, 484, thum. J. Czuj (Sw. Hieronim, Listy, I-III, Warszawa 1952-1954), I 255; B. Labanca, Idee pedagogiche di S. Girolamo, Milano 1901; J.N. Brunner, Der heilige Hieronymus und die Mädchenerziehung auf Grund seiner Briefe an Läta und Gaudentitus, München 1910; L.G. Menneson, L'amitié chez Saint Jérôme, „Etudes” 140 (1914) 5-27; F. Cavallera, Le dernier séjour de S. Jérôme en Occident (382-385), BLE 21 (1920) 39-45; J. Schuster, L'influenza di S. Girolamo sui primordi della vita monastica in Roma, w: Miscellanea Geronimiana, Roma 1920, 115-122; F. Cavallera, Saint Jérôme et la vie parfaite, RAM 2 (1921) 101-127; F. Cazès, Saint Jérôme et la lecture des livres saints, Gand 1921; G. Venturini, San Girolamo formatore di anime, Roma 1921; F. Cavallera, Saint Jérôme, sa vie et son oeuvre, Louvain - Paris 1922, vol. I, 75-108 (Le séjour à Rome: Marcella - Paula - Lea - Asella - Blesilla); L. Ventura, La pedagogia del cristianesimo. I. Le origini e la patristica, Firenze 1924; A. Bardicchia, Il pensiero morale e pedagogico di S. Girolamo, Matera 1925; D. Gorce, La lectio divina, vol. I: S. Jérôme et la lecture sacrée dans le milieu ascétique romain, Paris 1925; A. Casamassa, I due soggiorni di S. Girolamo a Roma, Roma 1926; J. Leclercq, Jérôme, DACL VII 2252-2260 (Séjour à Rome); D. Gorge, Les dames romaines à l'école de saint Jérôme, Paris 1928; A. Zuccoli, La vita dello spirito nella concezione di S. Girolamo Dalmata, "Archivio Storico per la Dalmazia” 12-14 (1932-1933) 235-250; J. d'Ivray, Saint Jérôme et les dames de l'Aventin, Paris 1937; Ch. Favez, Trois disciples de S. Jérôme: Marcella, Fabiola, Paula, „Etudes des Lettres” 12 (1938) 218-232; A.M. Sticco, Epistole di S. Girolamo alle patrizie romane, Milano 1940; A Penna, S. Gerolamo, 
a być może Marcelina, siostra św. Ambrożego oraz siostra papieża DamazegoIrena.

Torino 1949, 75-92 (Il cenacolo dell'Aventino); E. Burke, St. Jerome as a spiritual director, w: A monument to St. Jerome, ed. X.F. Murphy, New York 1952, 145-169; G.D. Gordini, Forme di vita ascetica a Roma nel IV secolo, „Scrutinium theologicum” 1 (1953) 7-58; J. Czuj, Sw. Hieronim. Żywot, dzieła, charakterystyka, Warszawa 1954; R. Metz, La consécration des vierges dans l"Eglise Romaine, Paris 1954, 77-87 (Les vierges chrétiennes à Rome); C.D. Gordini, Origine e sviluppo del monachesimo a Roma, „Gregorianum” 37 (1956) 220-260; J. Steinmann, Hieronymus, Ausleger der Bibel, Köln 1961, 117-148 (Der Zirkel auf dem Aventin); P.R.L. Brown, Aspects of the christianization of the Roman aristocracy, ,Journal of Roman Studies” 51 (1961) 1-11, lub w: Religion and Society, London 1972, 161-182; A. Ollivier, Hieronymus, Stuttgart 1965, 25-31 (Seelenführer im Aventinkreis); L. Laurita, Insegnamenti ascetici nelle lettere di S. Girolamo, diss., Nocera Superiore 1967; M. Turcan, Saint Jérôme et les femmes, „Bulletin de l'Association G. Budé” (1968) 259-272; Y. Bodin, Saint Jérôme et les laics, REAug 15 (1969) 133-147; M. Testard, Saint Jérôme, Paris 1969, 29-36 (Rome: la mission du savant, le directeur spirituel); A. Yarbrough, Christianization in the fourth century: the example of Roman women, „Church History” 45 (1976) 149-165; Y. Chauffin, Swięty Hieronim, tlum. B. Durbajlo, Warszawa 1977, 96-115 (Przybytek ducha); Ph. Rousseau, Ascetics, authority and the Church. In the age of Jerome and Cassien, Oxford 1978; F.E. Consolino, Modelli di comportamento e modi di santificazione per l'aristocrazia femminile d'Occidente, w: Società romana e Impero tardoantico, vol. I, ed. A. Giardina, Bari 1986, 273-306, 684-699; M. Sanchez - Maria del Mar, La visión de la mujer en san Jerónimo a través de su corespondencia, w: La mujer en el mundo antiguo. Actas de las quintas jornadas de investigacion interdisciplinaria, Madrid 1986, 315-321; tenże, Mulier sancta et venerabilis, mulier ancilla diaboli en la corespondencia de San Jerónimo, „Studia Historica. Historia Antiqua” 4-5 (1986-1987) 235-244; A. Arjava, Jerome and women, „Arctos. Acta Philologica Fennica” 23 (1989) 5-18; S. Dominique Eck, Les femmes autour de saint Jérôme, „Connaissance des Pères de l'Eglise” 1989, nr 36, 18-22; A. Ceresa - Castaldo, Figure e motivi femminili nell'epistolario di San Girolamo, "Orpheus” 13 (1992) 77-83; St. Rebenich, Hieronymus und sein Kreis, Salzburg 1992; Ch. Krumeich, Hieronymus und die christlichen "feminae clarissimae", Bonn 1993; S. Elm, ,Virgins of God": the making of ascetism in late antiquity, Oxford 1994; G. Jenal, Italia ascetica atque monastica. Das Asketen und Mönchtum in Italien von den Anfängen bis zur Zeit der Longobarden (ca. 150/250-604), Stuttgart 1995, 33-64 (Marcella, Paula, Bläsilla, Furia, Eustochium, Paula, Läta, Asella, Fabiola, Irene, Melania); Ph. Rousseau, "Learned women" and the development of a Christian culture in late antiquity, „Symbolae Osloenses” 70 (1995) 116-147, szczególnie: 131-143; L. Mirri, La dolcezza nella lotta. Donne e ascesi secondo Girolamo, Magnano 1996, 87-165 (Le discepole di GirolamoI cenacoli dell'Aventino - La vita delle fraternità domestiche), 289-303 (La scuola geronimiana); M. Testard, Les dames de l'Aventin, disciples de Saint Jérôme, „Bulletin de la Société nationale des antiquaires de France", 1996, 39-63; P. Laurence, Les moniales de l'aristocratie. Grandeur et humilité, VigChr 51 (1997) 140-151; tenże, Jérôme et le nouveau modèle feminin; la conversion à la „vie parfaite”, Paris 1997; Ch. Steininger, Die ideale christliche Frau: virgo-vidua-nupta. Eine Studie zum Bild der idealen christlichen Frau bei Hieronymus und Pelagius, St. Ottilien 1997; P. Laurence, Jérôme, la culture grecque et les femmes, w: Les apologists chrétiens et la culture grecque, red. B. Pouderon - J. Doré, Paris 1998, 315-331; G. Viden, St, Jerome on female chastity: subjugating the elements of desire, „Symbolae Osloenses” 73 (1998) 139-157; D. Zittel, Hieronymus und Paula: Brief an eine Asketin und Mutter, w: Frauenwelten in der Antike: Geschlechterordnung und weibliche Lebenspraxis, hrsg. Th. Späth - B. Wagner-Hasel, Stuttgart 2000, 426-437; J.N.D. Kelly, Hieronim. Życie, pisma, spory, tlum. R. Wiśniewski, Warszawa 2003, 108-122 (Marcela, Paula, Eustochium). 
Grupa tych arystokratek, które w większym lub mniejszym stopniu, glównie pod moralnym patronatem Marceli, praktykowaly ascezę religijną, jest przez niektórych współczesnych badaczy nazywana ,awentyńskim wieczernikiem" (cenaculum), a nawet, za św. Hieronimem, pierwszym w Rzymie żeńskim „klasztorem” (monasterium), zaś jedna z uczestniczek - Lea „przełożoną klasztoru i matką dziewic" (monasterii princeps - mater virginum) ${ }^{2}$.

O tego typu swoistym „klasztorze” można mówić w sensie przenośnym, ponieważ życie ascetyczne prowadziły w swoich domach indywidualnie, bez ustalonej reguly. Ich sposób życia świadczy jednak dobitnie, że chrześcijaństwo praktykowane na serio, a nie koniunkturalnie, w 2. pol. IV wieku ogarnęło również najwyższe arystokratyczne rody rzymskie, gdzie tworzyła się kobieca inteligencja chrześcijańska, która bez wątpienia położyła fundamenty pod żeński monastycyzm w Rzymie. Jednak ani asceza, ani wykształcenie kobiet nie było wówczas popularne w na ogół jeszcze pogańskim Rzymie, „mieście przepychu, rozwiązłości i uciech, gdzie być pokornym oznaczało nędzę"3, „mieście, które było niegdyś miastem narodu świata i siedliskiem występków - bo wszystko co szlachetne ponizali, a to co czyste i prawe, plamili" ${ }^{4}$. Tę stolicę Cesarstwa, jeden ze współczesnych historyków tak charakteryzuje:
„W drugiej połowie IV wieku Rzym miał 18 tysięcy hektarów powierzchni i w tym równie rozległym, co dzisiejszy Paryż mieście, wznosiło się prawie sto świątyń bądź dużych sanktuariów. Podzielone było na 14 dzielnic, a z centrum w stronę przed- mieśc bieglo około 30 ulic. Tyber przecinalo dziewięć kamiennych mostów, takich, jakie do dziś jeszcze zachowały się w okolicach, gdzie panowanie rzymskie wy- warło szczególnie silne piętno. Ówczesny Rzym to miasto 12 forów, 12 bazylik, przeszlo 40 luków tryumfalnych, 28 bibliotek, 330 kaplic, 1352 fontann, 11 akwe- duktów z 8 odgałęzieniami, 20 dużych posągów konnych (Equi magni), 164 po- sągów bogów złoconych lub z kości słoniowej i 3785 posągów z brązu przedsta- wiających sławnych mężów. Okazałe budowle administracyjne cechowal niebywa- ky przepych. Archiwa na forum u stóp Kapitolu i siedziba prefekta miasta budziły powszechny podziw. Palace otaczały rozlegle ogrody. Parki i sadzawki zajmowały jedną czwartą powierzchni miasta"

W takim to środowisku powstawały ascetyczne grupy tworzone przez wdowy i dziewczęta. Zrozumienie wartości ewangelicznych zaowocowało. Arystokratki bowiem zaczęły pogardzać przepychem, majątki swe często rozdawały ubogim, a poszukując głębszego sensu życia rezygnowały $\mathrm{z}$ małżeństwa i w zaciszu domowym poświęcały się medytacjom oraz lekturze Pisma św. i ksiąg teologicznych. Spotykały się, aby posłuchać ascetycznych konferencji,

\footnotetext{
${ }^{2}$ Por. Epistula 23, 2 (do Marceli), Czuj I 163; Penna, S. Gerolamo, Torino 1949, 76-77.

${ }^{3}$ Epistula 24, 5, PL 22, 428, Czuj I 167.

${ }^{4}$ Epistula 127, 3, PL 22, 1088, Czuj III 275-276.

5 Y. Chauffin, Swięty Hieronim, thum. B. Durbajło, Warszawa 1977, 96.
} 
dotyczących Pisma św., i przedyskutować tematy religijne, przyczyniając się w ten sposób do krzewienia kultury chrześcijańskiej.

Zorganizowaną formę spotkania te przybrały dopiero po przybyciu św. Hieronima do Rzymu. Zaproszony do Wiecznego Miasta, głównie jako tllmacz, przez papieża Damazego z okazji synodu rzymskiego w 382 r. wraz z przybywającymi ze Wschodu biskupami Paulinem i Epifaniuszem, wkrótce zwrócił na siebie uwagę rzymskiej arystokratki Marceli ${ }^{6}$. Był przecież sekretarzem papieża i miał opinię nie tylko wybitnego biblisty, ale i surowego ascety. Marcela doceniła wagę kontaktu z taką osobą i postanowiła wykorzystać św. Hieronima, męża zaprawionego w cnotach i obeznanego ze wschodnią ascezą, jako duchowego kierownika swojcj nieformalnej grupy. Jednak nie od Marceli, ani nie od św. Hieronima rozpoczęły się tego rodzaju praktyki, gdyż tradycja taka, choć bez sprecyzowanych norm, istniała już wcześniej, tworząc niekiedy spontanicznie powstające wspólnoty życia intelektualno-ascetycznego. Hieronim bowiem je tylko zorganizował i nadał in bardziej racjonalny charakter.

Już wcześniej w Rzymie, gdzie wszelkie praktyki ascetyczne, zwłaszcza ślub dziewictwa, uchodziły za rzecz co najmniej śmieszną, na początku IV wieku miała istnieć jakaś wspólnota dziewic założona przez Konstancję, córkę cesarza Konstantyna, wzorująca się na św. Agnieszce ${ }^{7}$. Również prawdopodobne było dziewictwo ślubowane przez Irenę, siostrę późniejszego papieża Damazego. Potem wiadomości o rozwijającym się na Wschodzic życiu mniszym, o jego założycielach św. Antonim $(† 356)$ i św. Pachomiuszu ( $† 346)$ oraz rzeszach naśladujących ich ascetów $\mathrm{i}$ ascetek, przywozili do Rzymu uciekający przed prześladowaniami (podczas sporów ariańskich) św. Atanazy ze swymi egipskimi towarzyszami Izydorem i Ammoniuszem (w latach 340-341 i w 347), później Piotr, jego następca na biskupiej stolicy aleksandryjskiej ${ }^{9}$. Od nich to rzymska

${ }^{6}$ Por. Epistula 127, 7, PL 22, 1091, Czuj III 280: „Musiałem w sprawach Kościoła udać się do Rzymu ze święlymi kapłanami Paulinem i Epifaniuszem (pierwszy z nich kierowal kościolem antiocheńskim w Syrii, drugi - salamińskim na Cyprze) i gdy skromnie unikałem oczu szlachetnych niewiast, tak zabiegała według Apostoła «w porę czy nie w porę» $(2 \operatorname{Tm} 4,2)$, że przemogła moją skromnośc swoim usilnym staraniem".

7 Por. Ambrosius, Epistula I ex ambrosiarum numero segregata, PL 17, 820: „Constantia Augusti filia in virginitate, per quam multae virgines et mediocres et nobiles et illustres sacra velamina suceperunt. Et quia fides mortis damna non patitur, usque in hodiernum diem multae virgines Romae Agnem beatissimam quasi in corpore manentem aspiciunt et eius exemplum agentes viriliter et integre perseverant".

${ }^{8}$ Por. G.D. Gordini, L'opposizione al monachesimo a Roma nel IV secolo, w: Dalla Chiesa antica alla Chiesa moderna, Roma 1983, 19-35; Jenal, Italia ascetica, s. 57-58.

${ }^{9}$ Por. Epistula 127, 5, PL 22, 1089-1090, Czuj III 278: „W owym czasie żadna spośród szlachetnie urodzonych niewiast w Rzymie nie znała ślubów zakonnych i nie odważyła się na to, żeby zasłużyć u ludzi z powodu nowości tego zagadnienia na jaką nazwę znieslawiająca - bo tak wtedy sądzono - i podłą. Ona od kapłanów aleksandryjskich i ojca Atanazego, a potem Piotra, którzy uchodząc przed prześladowaniem herezji ariańskiej uciekli do Rzymu, jakby najniebezpieczniejszego wspólnego portu, dowiedziała się o życiu jeszcze wtedy żyjącego błogosławionego 
matrona Marcela uzyskiwała informacje o życiu monastycznym. Ich postawa i przywożone przez nich ze Wschodu wiadomości zachęcały niektóre arystokratki do spotykania się i wspólnego praktykowania ascezy.

Również w dziedzinie intelektualnej, w poszukiwaniu wyższej wiedzy religijnej, miały one swoje poprzedniczki zarówno w świecie pogańskim, jak i chrześcijańskim. Można tu wymienić przynajmniej kilka kobiet, które już wcześniej zajmowały się m.in. filozofią ${ }^{10}$. Tak na przykład do kręgu neoplatonika Plotyna (204-269) w Rzymie po 245 r., reprezentowanego później przez chrześcijańskiego konwertytę Mariusza Wiktoryna i jego pogańskich kolegów - senatorów Symmacha i Pretekstata ${ }^{11}$, należały również patrycjuszki. Sam Plotyn żył w domu jednej ze swych wielbicielek - Geminy, żony Wibiusza Gallusa, późniejszego cesarza (251-253). Jego uczeń Porfiriusz w żywocie swego mistrza stwierdza, że „miał on również wielce sobie oddane kobiety”,12 dodając, że zarówno dziewczęta, jak i chłopcy korzystali z jego nauki. Sam zresztą Porfiriusz ożenił się z jedną z takich filozofek - Marcelą. Z listu skierowanego do niej wynikało, iż uznał ją za równą sobie pod względem intelektualnym. Czuł się też w obowiązku do wychowania jej siedmiorga dzieci, mając nadzieję, że one również pokochają filozofię ${ }^{13}$.

Następną interesującą postacią kobiecą w pogańskiej tradycji filozoficznej była - opisana pod koniec IV wieku przez Eunapiusza z Sardes w jego Żywotach sofistów - Sosipatra z Kapadocji, żona Eustatiosa, kierownika neoplatońskiej szkoły w Kapadocji, która „swą wyjątkową wiedzą przewyższała znacznie swego męża"14. Wywodząc się $\mathrm{z}$ arystokratycznej rodziny, już w młodości

Antoniego, a także o klasztorach w Tebaidzie, o karności (zakonnej) Pachomiusza, dziewic i wdów. Nie wstydziła się wyznawać tego, co - jak się przekonała - podoba się Chrystusowi. W jej ślady poszla po wielu latach Sofronia i inne"; zob. także G.D. Gordini, Origine e sviluppo del monachesimo a Roma, „Gregorianum” 37 (1956) 229-232; I. Gobry, Storia del monachesimo I, pp. 111-114 (Tipi di vita consacrata femminile nel sec. IV); G. Bardy, Les origins des écoles monastiques en Occident, SE 5 (1953) 87-89.

${ }^{10}$ Por. Ph. Rousseau, "Learned women" and the development of a Christian Culture in late Antiquity, „Symbolae Osloenses” 70 (1995) 116-147, spec. 117-125.

${ }_{11}$ Por. A. Cameron, Paganism and literature in Late Fourth Century Rome, w: Christianisme et formes littéraires de l'antiquité tardive en Occident, „Entretiens” 23 (1977) 1-40; tenże, The Latin Revival of the Fourth Century, w: Renaissances before Renaissance. Cultural revivals of the Late Antiquity and the Middle Ages, ed. Warren Treadgold, Stanford 1984, 42-58.

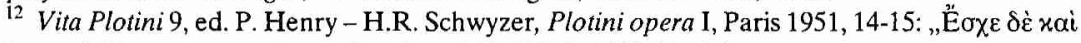

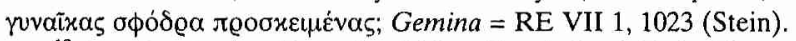

${ }^{13}$ Por. Porphyrius, Epistola ad Marcellam 1,3, ed. E. des Places; Porphyre, Vie de Pythagore. Lettre à Marcelle, Les Belles Lettres, Paris 1982, $103-104$ lub Eunapii Vitae sophistarum IV 2, 6 (457), ed. J. Giangrande, Rome 1956, 10.

${ }_{14}$ Eunapios, Vitae sophistarum VI 6, 5 (466), ed. J. Giangrande, Roma 1956, 28; por tamże VI 6, 12 (467); VI 8, 2 (469); VI 9, 12 (470); X 7, 9-10 (493); VII 1, 1 (473); VII 4, 15 (479); VII 4, 5-6 (477); R. Penella, Greek Philosophers and Sophists in the Fourth Century A.D. Studies in Eunapius of Sardis, Liverpool 1990, 53-55; Ph. Rousseau, „Learned women”, art. cyt., s. 118-120; G. Reale, 
otrzymała staranne wykształcenie. Mimo wychowywania trojga dzieci, potrafiła znaleźć czas na zgłębianie filozofii, ze swobodą cytowała poetów, filozofów i mówców starożytnych. W późniejszych latach, po śmierci męża, prowadziła seminaria naukowe w neoplatońskiej szkole w Pergamonie. Jej syn Antoninus, osiadły w Aleksandrii, zostawszy jej następcą, założył szkołę w delcie Nilu koło Kanobos, budując duchowy pomost między matką a filozofką Hypatią.

Kolejną więc uczoną kobietą byla „boska" Hypatia z Aleksandrii, córka znanego matematyka Teona. Chociaż sama była poganką, to jednak jej uczniowie w większości byli chrześcijanami, a wśród nich najwybitniejszy - Synezjusz z Cyreny (370-414), biskup Ptolemaidy w Północnej Afryce. Trzeba zaznaczyć, że korespondował $\mathrm{z}$ nią aż do końca życia ${ }^{15}$. Zainteresowania tej wybitnej uczonej koncentrowaly się bardziej na matematyce $i$ astronomii niż na filozofii. Była fascynującą kobietą. Męski sposób bycia, niekiedy może zbyt prowokacyjny, wywoływał często zgorszenie u współczesnych. W jej domu gromadziło się wielu uczonych i uczniów, którym służyła swoją wiedzą. W 415 r. została rozszarpana na ulicy przez fanatyczny tłum i mnichów posądzających ją o wrogi stosunek do chrześcijaństwa ${ }^{16}$.

Wśród chrześcijan także zaczęly pojawiać się mniej lub bardziej wykształcone kobiety, wywodzące się najczęściej z arystokratycznych rodów. Można tu wskazać na żonę konsula Adelfusa - Probę, która w latach 360-380 ułożyła centon z 394 wersów Wergiliusza, opowiadający o stworzeniu świata, upadku pierwszyclı rodziców i o życiu Chrystusa ${ }^{17}$. Ta kompilacja mająca sens zupełnie inny od myśli przewodniej utworu, z którego zaczerpnięto materiał, wymagała z pewnością dobrej znajomości literatury klasycznej. Utwór ten bez wątpienia przeznaczony był dla wykształconych sfer arystokratycznych. Zostal jednak krytycznie oceniony przez św. Hieronima (garrula anus - gadatliwa babcia), św. Jana Chryzostoma i św. Augustyna (docta ignorantia - uczona ignoran-

Historia filozofii starożytnej, thum. I. Zieliński, IV, Lublin 2002, 441; Seek, Pauly-Wissowa III 2, 1167.

${ }^{15}$ Listy Synezjusza do Hypatii: X, XV, XVI, XLVI, CXXIV, LXXXI, CLIII; Listy Hypatii: CXXXIII, CXXXVI, CXXXVII, ed. A. Garzya: Synesii Cyrenensis Epistolae, Roma 1979; PG 66, $1321-1560$.

${ }^{16}$ Por. J.M. Rist, Hypatia, „Phoenix” 19 (1965) 214-225; A. Cameron - J. Long, Barbarians and Politics at the court of Arcadius, Berkeley - Los Angeles - Oxford 1993, 50-65; M. Dzielska, Hypatia z Aleksandrii, Kraków 1993; Praechter, Hypatia, RE IX 1, 242-249.

17 Por. Cento, ed. C. Schenkl, CSEL 16, 569-609; E.A Clark., The Vergilian Cento of Faltonia Betitia Proba, „Studia Patristica” 17 (1982) 412-416; D. Shanzer, The anonymous «Carmen contra paganos" and the date and identity of the centonist Proba, „, Revue des Etudes Augustiniennes" 32 (1986) 232-248; J. Matthews, The Poetess Proba and Fourth Century Rome: Questions of interpretation, w: Institutions, société et vie politique dans l'empire romain au IV siècle après J.C., ed. M. Christol, Roma 1992, 277-304; M. Cytowska - H. Szelest, Literatura rzymska. Okres cesarstwa: autorzy chrześcijaniscy, Warszawa 1994, 191-193; Ph. Rousseau, Learned women, s. 121-124; DPAC II 2907-2908. 
cja $)^{18}$, a ich zdanie w dużym stopniu liczylo się w ówczesnym świecie kształtującej się kultury chrześcijańskiej.

Inną wykształconą arystokratką byla Olimpiada, żona Nebridiusza, prefekta Konstantynopola, wychowywana przez Teodozję, siostrę Amfilocha z Ikonium. Po śmierci męża (386 r.) zostala diakonisą i wraz z innymi kobietami stworzyla wspólnotę mającą na celu niesienie pomocy potrzebującym. Przyjaźniła się z Grzegorzem z Nazjanzu i Grzegorzem z Nyssy oraz z Janem Chryzostomem, który skierowal do niej aż 17 listów $^{19}$ i wysoko cenił wspólpracę $\mathrm{z}$ tą wspólnotą.

Wiemy również, że do elity intelektualnej należały matka i siostra św. Bazylego i św. Grzegorza z Nyssy - Makryna, siostra św. Ambrożego - Marcelina, a także matka św. Augustyna - Monika ${ }^{20}$.

Do tych właśnie ascetyczno-intelektualnycl tradycji nawiązywała Marcela, której pałac na Awentynie był miejscem spotkań rzymskich arystokratek. Wraz ze swą matką Albiną stała się ona jakby zwornikiem i „spiritus movens" tych imprez. Głównym źródłem informacji o jej działalności jest 127 list św. Hieronima do jej uczennicy - Pryncypii ${ }^{21}$.

Marcela pochodzila $\mathrm{z}$ jednego $\mathrm{z}$ najstarszych i najstynniejszych rodów rzymskich $-z$ rodu Marcellusów (wg innych Klaudiuszów) - $z$ rodziny, mającej „szlachectwo wysokiej krwi i szereg przodków, wśród których byli konsulowie i prefekci pretorianów"22. Urodzona ok. $330 \mathrm{r}$. od wczesnych lat przeżywała rodzinne dramaty; jako dziecko straciła ojca, a później wydana za mąż zaledwie

${ }^{18}$ Por. Epistula 53, 7, PL 22, 544, Czuj I 356: „Gadatliwa staruszka” oraz Joannes Chrysostomus, Epistulae 168-170, PG 52, 710; Augustinus, Epistula 130, CSEL 44, $40-77$ (Ad Probam).

19 Por. Palladius, Dialogus X 16, PG 47, 35-61; Historia Lausiaca 56, 1 i 61, 3; Sozomenos, HE VIII 9,24 i 27, PG 67, 1538; Joannes Chrysostomus, Epistulae ad Olympiadem, SCh 13bis: Lettres à Olympias, tłum. W. Kania PSP 13, 250-291 (Ep. 1-2, 7-12, 16-17); Vita Olimpiadis, SCh 13bis, 406449; A.M. Malingrey, Introduction, tamże, spec. 40-53 (Jean et Olympias); BS IX 1154-1158; DPAC II 2462-2463; Ph. Rousseau, Learned women, s. 129-131.

${ }^{20}$ Por. Ph. Rousseau, Learned women, art. cyt., s. 124-129.

${ }^{21}$ Por. Epistula 127, PL 22, 1087-1095, Czuj III 274-286; także listy 23-29, 32, 34, 37-38, 40-44, $46,59$.

22 Epistula 127, 1, PL 22, 1087, Czuj III 274; por. Acta SS. Januarii, III, Paris 1863, 720-724; BHL II p. 775, nr 5222; L. Pauthe, Histoire de St. Marcelle, Paris $1884^{2}$; G. Grützmacher, Hieronymus, Leipzig 1901, I 225-242 i III 193-198; F. Cavallera, St. Jérôme: sa vie et son oeuvre, I, 85-89, 114-119; Vies des Saints, I, Paris 1935, 633-634; Ch. Favez, Trois disciples: Marcella, Fabiola, Paula, „Etudes des lettres” 12 (1938) 218-232; A. Penna, Girolamo, s. 74-85; P. Antin, Essai sur saint Jérôme, Paris 1951, 81-88; D. Gorce, S. Jérôme et la lecture sacrée dans le milieu ascetique romain, Wepion-sur-Meuse 1925, 192-210; Y. Chauffin, Święty Hieronim, Warszawa 1977, 102-107; B.M. Margarucci, S. Marcella, la sua società in Roma e fuori, „L'Urbe” 38 (1975) 6-15; BS VIII 644-646 (C.D. Gordini); Jenal, Italia ascetica, s. 34-42; Catholicisme VIII 407-408 (J. Daoust); DACL X 1760-1762 (H. Leclercq); P. Laurence, Marcella, Jérôme et Origène, REA 42 (1996) 267-293; N. Adkin, Jerome on Marcella: Epistula 127, 10.4, „Bolletino di Studi Latini” 29 (1999) 564-570; DSp X 295 (A. Solignac); ECat VIII 8 (E. Romanelli); LThK $^{2}$ VI 1375-1376 (A.P. Frutaz); LThK $^{3}$ VIII 1299 (H. Grieser); DPAC JI 2085-2086 (M.C. Bianco); DIP V 898. 
po 6 miesiącach została wdową. W latach 340-341 w jej rodzinnym domu gościł przebywający na wygnaniu św. Atanazy Aleksandryjski. Opowiadał jej o rodzącym się w Egipcie życiu monastycznym, o ojcach pustyni, zwłaszcza o św. Antonim Pustelniku, którego żywot opisal i przywiózl ze sobą. Przekazane nauki głęboko utkwiły w duszy dziesięcioletniej dziewczynki i wpłynęły niewątpliwie na jej późniejszą decyzję - rezygnacji z ponownego małżeństwa i podjęcia życia w czystości. Św. Hieronim tak o niej pisze:

\begin{abstract}
„Osierocona już przez śmierć ojca i męża również straciła w sześć miesięcy po ślubie. Cerealis, którego imię sławne jest wśród mężów konsularnych, $\mathrm{z}$ wielkimi zabiegami starał się o nią z powodu jej wieku i starożytności rodu, a także wybitnej urody - co zwykle najbardziej się mężczyznom podoba - oraz powściągliwości obyczajów. Człlowiek ten w podeszłym wieku obiecywał swe bogactwa i chcial je przekazać jej w darze nie jak żonie, lecz jak córce, a matka Albina chętnie się godziła na tak świetną opiekę dla wdowiego domu. Ona wtedy odpowiedziala: «Gdybym chciała wyjść za mąż, a nie pragnęła poświęcić się dozgonnej czystości, to szukałabym z pewnością małżonka, a nie dziedzictwa». A gdy on zauważył, że. i starcy mogą żyć długo, i mlodzieńcy prędko umrzeć, odparła uprzejmie: «Wprawdzie młodzieniec może prędko umrzeć, ale starzec dlugo żyć nie może». Taką odpowiedzią odrzucony stanowił on przykład dia innych, aby postradali nadzieję na małżeństwo $\mathrm{z}$ nią" 23 .
\end{abstract}

Sama odtąd zaczęła ubierać się skromnie, majątek rozdawać ubogim, i co istotne, skupiać wokół siebie żyjące w podobny sposób rzymskie arystokratki. Hieronim zaznacza, że była ona pierwszą wdową rzymską, która do arystokratycznych pałaców zaczęla wprowadzać zasady życia monastycznego:

„Ona pierwsza zawstydziła pogaństwo swoim przykładem pokazując wszystkim, jakie powinno być chrześcijańskie wdowieństwo, które przyrzekła w sumieniu i odzieniem podkreślała. Inne bowiem zwykle malują usta czerwona sszminką, świeca jedwabnymi szatami, blyszczą klejnotami, noszą złote naszyjniki i w przeklutych uszach wieszają bardzo cenne ziarna Morza Czerwonego, pachną piżmem, małżonków opłakują ciesząc się raczej, ze wreszcie pozbyły się ich panowania, a szukają innych nie po to, aby im według wyroku Bożego służyć, ale aby im rozkazywać. Dlatego też wybierają nawet ubogich, byleby tylko wyglądało, że mają mężów; a oni muszą cierpliwie znosić rywalów, gdyby bowiem szemrali, prędko zostaliby porzuceni. Nasza wdowa takich używała szat, aby chronić się przed zimnem, a nie odsłaniać ciało, gardziła złotem, tak że nawet sygnelu nie nosiła, i oddawała je raczej na pożywienie dla ubogich, a nie chowała w sakwach. Nigdy bez matki ani bez świadków nie widywała żadnego z duchownych i mnichów, a to było niekiedy konieczne $w$ wielkim domu. Zawsze miała obok siebie dziewice i wdowy, a nawet poważne niewiasty, wiedząc, że ze swawoli dziewcząt sądzi się często o obyczajach pań i że jaka jest która $\mathrm{z}$ nich, w takim lubi przebywać towarzystwie" ${ }^{24}$.

${ }^{23}$ Epistula 127, 1, PL 22, 1087, Czuj III 274.

24 Tamże, 127, 2, PL 22, 1087-1088, Czuj III 275. 
W pełnym przepychu rodzinnego domu prowadziła umartwione życie; praktykowała posty oraz wstrzemięźliwość od niektórych pokarmów, unikała wizyt w innych domach i miejscach publicznych. Wychodziła jedynie na modlitwę do kościoła. Każdą wolną chwilę poświęcała czytaniu Pisma św., medytacjom oraz śpiewaniu psalmów; Hieronim nazywa ją „ozdobą wszystkich świętych i samego Rzymu [...], która wzgardziwszy dostatkami i szlachectwem stała się jeszcze szlachetniejszą przez ubóstwo i pokorę"25.

„Zachowywała umiarkowane posty, wstrzemięźliwość od mięsa i znała raczej zapach wina niż jego smak, używając je ze względu na żołądek i częste niedomagania. Rzadko wychodzila na widok publiczny, a najbardziej unikała domów matron szlacheckiego pochodzenia, aby nie musiała widzieć tego, czym wzgardziła. W tajemnicy modliła się w bazylikach Apostołów i męczenników oraz w tych, w których nie było natloku ludzkiego. Matce do tego stopnia byla posłuszna, że często postępowała wbrew swojej woli. Gdy tamta nie dbając o swą córkę, a nie mając synów ani wnuków chciała oddać wszystko dzieciom brata, ona, chociaż wybierała ubogich, jednak nie umiała się sprzeciwiać matce; naszyjniki i wszystkie sprzęty ustąpila bogatym, jako rzeczy, które mają zginąć, i wolała raczej utracić pieniądzc ni்̇ zasmucić serce matki"26.

Marcela wraz z innymi arystokratkami realizowała program ascetyczny, o którym dowiedziala się już jako dorastająca dziewczynka od św. Atanaze$\mathrm{go}^{27}$, a później także od mnichów wschodnich, zwłaszcza biskupa Piotra Aleksandryjskiego, którzy u niej gościli. W ten sposób dom Marceli tuż po 373 r. stał się małym asketerionem, stanowiącym zalążek i zapowiedź żeńskiego klaszto$\mathrm{ru}^{28}$, choć jeszcze bez sprecyzowanej reguły. Praktykowano w nim nie tylko umartwienie, pokutę i ascezę, ale i poszerzano znajomość Pisma świętego. Według tego programu ascetycznego żyła nie tylko sama, ale $\mathbf{i}$ jej inne arystokratyczne towarzyszki, jak Sofronia, Asela, Pryncypia, Marcelina, Lea, Paula i Eustochium, które ją odwiedzały, razem z nią się modliły, czytały i medytowały Pismo święte.

Gdy Marcela dowiedziała się, że w 382 r. przybył do Rzymu słynny egzegeta św. Hieronim ${ }^{29}$, nie zawahała się, ale naleganiami skłoniła go do objęcia nad jej grupą duchowego kierownictwa i objaśniania im Pisma świętego. Hieronim pelnił tę funkcję przez 3 lata $^{30}$, czyniąc ich uczestniczki swoimi serdecznymi

\footnotetext{
${ }^{25}$ Tamże 127, 3, PL 22, 1088-1089, Czuj III 276-277.

${ }^{26}$ Tamże 127, 1, PL 22, 1087, Czuj III 274.

${ }^{27}$ Tamże 127, 4, PL 22, 1089, Czuj III 277-278.

${ }^{28}$ Por. wyżej nota 9.

${ }^{29}$ Por. C.D. Gordini, Origine e sviluppo del monachesimo a Roma, „Gregorianum” 37 (1956) 220-260, szczególnie 225-229.

${ }^{30}$ Por. Epistula 45, 2, PL 22, 481, Czuj I 252: „Prawie przez trzy lata żyłem z nimi; często wielki thum dziewic mię otaczał; Boskie Księgi, jak mogłem, niektórym objaśniałem; czytanie pociągnęło za sobą częste obcowanie, częste obcowanie zażyłość, a zażyłość zaufanie".
} 
duchowymi córkami. W gronie tych uczennic i słuchaczek wyróżniała się pani domu - Marcela, która znając język grecki nauczyła się również języka hebrajskiego i stawiała mu wiele kłopotliwych pytań, uważając się przy tym - jak sam pisze - za najwierniejszą jego uczennicę:

„A ponieważ miałem wtedy jakąś sławę z powodu studiów biblijnych, dlatego nigdy się nie zdarzyło, żeby nie pytała o coś z Pisma św.; i nie godzila się na to natychmiast, ale poruszała przeciwne kwestie nie dla sprzeczania się, lecz dlatego, żeby przez pytanie uczyć się rozwiązywania zagadnień, jakie według jej rozumienia mogą być wysunięte. [...] To tylko powiem, że cokolwiek przez dlugie studia zdobyłem i przez ciągle rozmyślanie jakby w naturę obróciłem, tego wszystkiego ona skosztowala, tego się nauczyla i to posiadła, tak że jeśli po moim odjeździe powstal spór, co do jakiegoś świadectwa Pisma św., do niej spieszono, jako do sędziego. A że byla bardzo roztropna i znala to, co filozofowie nazywaja tò

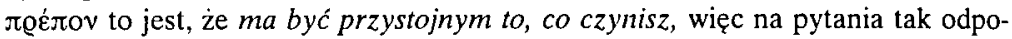
wiadała, iż nawet swoich poglądów nie nazywała swymi, lecz albo moimi, albo kogokolwiek innego, aby także w tym, czego uczyła, uważano ją za uczennicę"31.

Między Hieronimem a Marcelą zawiązała się wkrótce głęboka duchowa przyjaźn, która przetrwała także po jego wyjeździe w 385 r. do Palestyny. Owocem tej przyjaźni były listy, $\mathrm{z}$ których aż 17 ma charakter egzegetyczny i odpowiada na wiele trudnych pytań, np. o imionach Bożych (25), o diapsalmie (28), o znaczeniu wyrazów efod bad i terafim (29) i inne ${ }^{32}$. Marcela nie przeniosła się jednak do Palestyny, dokąd wyjechały jej przyjaciółki Paula i Eustochium, ale mimo nieobecności Hieronima prowadziła nadal życie ascetyczne w Rzymie. Przez szereg następnych lat jej dom na Awentynie pozostawal „wieczernikiem ascetycznym" dla dziewic i wdów. Nadal poszerzała, choć była kobietą, swą wiedzę teologiczną. Gdy pod koniec IV wieku przeniosła się z córką duchową - Pryncypią do swych podrzymskich posiadłości (ager suburbanus), gdzie „podmiejskie pola były im klasztorem, a wieś wybrały ze względu na samotność”33, przybył do Rzymu Rufin z Akwilei i wywołał spory orygenesowskie, Marcela była na tyle teologicznie przygotowana, ze wzięła w nich czynny udzial, przyczyniając się do potępienia Rufina przez papieża Anastazego ${ }^{34}$ :

„Ona dala początek potępienia heretyków: sprowadza świadków, którzy przedtem przyjęli ich naukę, a potem poprawili się $z$ heretyckiego błędu; wskazuje na wielką

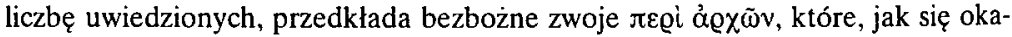
zuje, poprawione zostały ręką tego skorpiona [Rufina]; heretycy wezwani licznymi pismami, aby się bronili, nie odważyli się przyjść; tak wielka była siła sumienia, ze

31 Epistula 127, 7, PL 22, 1091, Czuj III 281.

32 Por. np. Listy 25-29, 32, 34, 37, 40, 42-44, 46, 59; zebrane stanowily księgę: Liber ad Marcellam, zob. De viris illustribus, PL 23, 758: „Ad Marcellam epistularum librum unum”.

33 Epistula 127, 8, PL 22, 1092, Czuj III 281.

${ }^{34}$ Por. Epistola Anastasii ad Simplicianum Mediolanensem = Hieronymi Epistola 95, PL 22, 772-774, Czuj II 275-276. 
woleli raczej być potępieni w czasie swej nieobecności niż jako obecni przekonać się o swej winie. Źródłem tego chwalebnego zwycięstwa jest Marcela"”35.

Prawdopodobnie była ona również u początków sporów pelagiańskich, spotykając się z uczniem Pelagiusza Celestiuszem ${ }^{36}$. Nadal utrzymywała żywe kontakty z Hieronimem, który dedykowal jej napisany przez siebie Komentarz do Księgi Daniela oraz wcześniej dla niej i jej kuzyna Pammachiusza Apologį przeciw Rufinowi (r. 401).

W 410 r. Marcela powróciła z Pryncypią do Rzymu z obawy przed inwazją Gotów. Podczas ich najazdu na Wieczne Miasto w sierpniu 410 r., odmówiwszy napastnikom żądanych pieniędzy, została skopana i pobita kijami, broniąc przy tym młodej Pryncypii przed zhańbieniem, z którą schroniła się do bazyliki św. Pawła za Murami, jako miejsca azylu. Wydarzenie to tak opisuje św. Hieronim:

„Opowiadają, że z nieustraszonym obliczem przyjęła wkraczających i gdy żądano złota. a ona pokazując nędzną tunikę wymawiała się od zakopania majątku, nie dano wiary dobrowolnemu ubóstwu. Mówią, że zbita kijami i biczami nie czuła mąk, lecz zalana łzami i kopana przez nich dokonała tego, że cię od jej towarzystwa nie oddzielono, aby młodość nie musiała znosić tego, czego starczy wiek nie mógł się obawiać. Zmiękczył Chrystus twarde serca i wśród krwawych mieczów znalazła litość. I gdy i ją, i ciebie odprowadzili barbarzyńcy do bazyliki błogoslawionego Apostola Pawła, aby wam zapowiedzieć albo ocalenie, albo grób"37.

Wkrótce jeszcze tego samego roku zmarła na rękach Pryncypii, duchowej spadkobierczyni jej ascetyczno-intelektualnej postawy, choć nigdy jej nie dorównała. Kościół rzymski czci ją jako świętą 31 stycznia.

O wiele mniej informacji many o pozostałych członkiniach żeńskiego klubu awentyńskiego, związanych bezpośrednio z Marcelą. Najbliższymi jej osobami były bez wątpienia jej matka Albina i wspomniana Pryncypia. Albina trzykrotnie wzmiankowana przez Hieronima, prawdopodobnie córka konsula z 335 r. Ceioniusa Rufinusa Albinusa, była typową przywiązaną do majątku rzymską arystokratką, który chciała zabezpieczyć a nawet powiększyć. Gdy jej córka Marcela wcześnie owdowiawszy nie dała się namówić na powtórne małżeństwo, przekazala cały swój wielki majątek dzieciom swego brata, a sama nawróciwszy się, także podjęła życie ascetyczne. Jako gospodyni i najstarsza z nich, gościła wielokrotnie w swoim domu wspóltowarzyszki Marceli, podejmujące tu praktyki ascetyczne i oddające się lekturze Pisma św., stając się ich wspólną matką ${ }^{38}$. Zmarła prawdopodobnie w 388 roku.

${ }^{35}$ Epistula 127, 10. PL 22, 1093, Czuj III 283.

${ }^{36}$ Por. A. Solignac, Marcella, DSp X 294.

37 Epistula 127, 13, PL 22, 1095, Czuj 285.

${ }^{38}$ Por. Epistula 127, 2, PL 22, 1088, Czuj III 275: ,a matka Albina chętnie się godzila na tak świetną opiekę dla wdowiego domu”; Epistula 143, 2, PL 22, 1182, Czuj III 414: „Swięte dzieci wspólne, Albina, Pinian i Melania, stokrotnie was pozdrawiają". 
Podobnie było $\mathrm{z}$ dziewicą Pryncypią przybraną przez Marcelę za córkę, która opiekowała się. nią aż do śmierci ${ }^{39}$. Hieronim skierowal do niej dwa listy: w 397 długi list (65) z objaśnieniem 44 Psalmu, o które prosiła, nazywając ją przy tym dziewicą i „córką" lub „córką w Chrystusie" ${ }^{40}$. Przypomina jej, że ma ona jako"wzory w studiowaniu Pisma oraz uświęcaniu umysłu i ciała Marcelę i Aselę", z których pierwsza „zawiedzie ją przez zielone łąki i rozmaite kwiaty ksiąg Bożych” do Pana, a druga „sama jest kwiatem Pana” ${ }^{\text {,4 }}$. Wynika $z$ tego, że i ta dziewica zainteresowana była egzegezą Pisma świętego. Drugim Iistem (127) skierowanym w 412 r. do Pryncypii było cytowane wyżej pośmiertne elogium Marceli ${ }^{42}$. Trzy inne damy $z$ tego towarzystwa, najprawdopodobniej dziewice, to Sofronia, Felicyta i Marcelina, które Hieronim tylko raz wspomina, nie podając o nich żadnych informacji ${ }^{43}$. Nie jest wykluczone, że tą ostatnią mogła być starsza siostra św. Ambrożego, która w Epifanię $353 \mathrm{r}$. zlożyła ślub czystości w Bazylice Watykańskiej wobec papieża Liberiusza, a potem mieszkała w Rzymie ${ }^{44}$; ona również, mając wówczas ok. 55 lat, mogla uczęszczać na Awentyn na wykłady o Biblii, goszczącego w Rzymie Hieronima. Można przypuszczać, że do awentyńskiego towarzystwa rzymskich arystokratek należala także siostra papieża Damazego-dziewica Irena ${ }^{45}$, choć Hieronim nie wspomina jej bezpośrednio ani razu. Trudno bowiem przypuszczać, żeby Hieronim będąc sekretarzem papieża ${ }^{46}$ nie znał jego siostry, a ona nie zechciała sluchać biblijnych konferencji slynnego egzegety.

O wiele więcej wiadomości przekazal Hieronim o pozostałych członkiniach awentyńskiego towarzystwa z otoczenia Marceli, a mianowicie o Lei, a zwłaszcza o Fabioli i Aseli.

O Lei pisze jedynie na wiadomość o jej śmierci w liście (23) do Marceli, która choć pozostawała $\mathrm{z}$ nią $\mathrm{w}$ bliskich stosunkach i bardzo przeżywała jej odejście, nie mogąc $z$ jakiegoś powodu uczestniczyć $w$ jej pogrzebie $w 384$

${ }^{39}$ Por. Epistula 127, 14, PL 22, 1095, Czuj III 286: „Zamknęła oczy na twoich rękach [Pryncypio]. oddała ducha w twoich oczach".

${ }^{40}$ Por. Epistula 65, 22, PL 22, 622-639, Czuj II 56-81, szczególnie 65, 1 i 65, 22, Czuj I 56 i 81: „Kiedy i Ty córko Principio, razem z chórem świętych wśród dziewic będziesz prowadzona do Króla; tamże 20, PL 22, 637, Czuj II 78: ,Sądzę, ze wśród tych dziewic, które idą za Kościołem i na pierwszym stawiane są stopniu, znajdziesz się i ty, i wszyscy, klórzy trwają w dziewictwie ciała i duszy".

${ }^{41}$ Tamże, 65, 2, PL 22, 624, Czuj II 58.

42 Por. Epistula 127, PL 22, 1087-1095, Czuj III 274-286.

43 O Sofronii por. Epistula 127, 5, Czuj III 278: „W jej [Marceli] ślady poszla po wielu latach Sofronia i inne"; Epistula 47, 7, Czuj I 255.

44 Por. BS VIII 646-648; PLRE I 544; DPAC II 2087. Brat Ambroży poświęcil jej specjalny traktat De virginibus oraz 3 listy $(20,22,41)$.

${ }^{45}$ Por. BS VIII 885; Jenal, Italia ascetica, s. 57-58.

46 Por. Penna, S. Gerolamo, s. 64-74 (Gerolamo ed il papa Damaso); Kelly, Hieronim, s. 96107 (Hieronim na dworze Damazego). 
roku. ${ }^{47}$. Była ona początkowo bogatą, żyjącą wystawnie rzymską arystokratą, która po wczesnym owdowieniu, odrzuciła drugie małżeństwo $z$ desygnowanym konsulem Agoriusem Pretestatem, nawróciła się i związala z domem Marceli. Podjęła pokutnicze, skromne i umartwione życie, zostawszy nawet przełożoną jakiegoś ugrupowania dziewic:

„Któż może godną pochwałą wyrazić życie naszej Lei? Tak calkowicie nawróciła się do Pana, że stała się przełożoną klasztoru i dziewic; nosiła kiedyś miękkie szaty, teraz workiem ciało umartwiała; noce spędzała na modlitwach i towarzyszki swoje więcej nauczyła przykładem niż słowami. Odznaczała się tak wielką i uległości pelną pokorą, że - niegdyś pani nad wieloma - mogłaby być uważana za sługę wszystkich, gdyby nie była raczej służebnicą Chrystusa niż panią ludzi. Prosta szata, skromny pokarm, głowa niepielęgnowana - we wszystkim jednak, co czyniła, unikała popisywania się przed innymi, aby nie wziąć nagrody na tym świecie ${ }^{48}$.

Trudno jest z powyższej zretoryzowanej charakterystyki wnioskować o jakiejkolwiek działalności Lei w domu Marceli. Musiała zapewne u niej bywać, skoro tak bardzo przeżyła jej odejście.

Bogatszą działalność, zwłaszcza charytatywną, prowadziła arystokratka Fabiola, która do awentyńskiego klubu Marceli włączyla się znacznie później, już po wyjeździe (385 r.) Hieronima do Betlejem. Jedynym biograficznym źródłem o niej jest panegiryczny 77 list Hieronima o jej śmierci, napisany w Betlejem w 399 r. na prośbę Oceana, ${ }^{49}$, a także dwa jego listy (64 i 78) bezpośrednio do niej skierowane ${ }^{50}$. Fabiola, wywodząca się z senatorskiej arystokratycznej rodziny rzymskiej (Quintus Maximus Fabius) została wcześnie wydana za występnego mężczyznę, którego jednak wkrótce porzuciła

${ }^{47}$ Por. Epistula 23, 1, PL 22, 426, Czuj I 162-163; G.D. Gordini BS VII 1157-1158; Vies des Saints, III, Paris 1941, s. 491; Penna, S. Gerolamo, s. 90; ECat VII 999 (R. Romanelli); Gordini, Origine e sviluppo del monachesimo a Roma, s. 235, 239, 245; LThK VI 247 (A.P. Frutaz).

${ }_{48}$ Por. Epistula 23, 2, PL 22, 426, Czuj I 163.

${ }^{49}$ Por. Epistula (de obitu Fabiolae) 77, PL 22, 690-698 lub CSEL 55, 37-49, Czuj II 158-170; zob. Penna, S. Gerolamo, s. 205-209; Ch. Favez, Trois disciples de S. Jérôme: Marcella, Fabiola, Paula, „Etudes des lettres” 12 (1938) 218-232; P. Antin, Essai sur S. Jérôme, Paris 1951, 198 i 203, 261; Vies des Saints, XII, Paris 1956, 723-730; Jenal, Italia ascetica, s. 55-57; BS V 431 (D. Balboni); DPACI 1327 (J. Gribomont); DHGE XVI 319-320 (D. Gorce); LThK III ${ }^{2} 1332$ (A. Frutaz); LThK III $^{3} 1147$ (H. Grieser); EK V 5-6 (J. Śrutwa); ECat V943 (E. Josi); Catholicisme IV 1035-1036 (G. Bardy); PLRE I 323.

${ }_{50}$ Por. Epistula 64, PL 22, 607-622 lub CSEL 54, 586-615, Czuj II 34-55; Epistula 78: De XLII mansionibus Israelitarum in deserto (O postojach synów izraelskich na pustyni), PL 22, 698-724 lub CSEL 55, 49-87, Czuj II 170-209; Epistula 126, 2, PL 22, 698-724, Czuj III 273: „Dwie księgi (listy 64 i 78) posłałem świętej córce mojej Fabioli. Ich egzemplarze, jeśli zechcesz możesz od niej pożyczyć, innych $z$ braku czasu nie mogłem napisać;” Adversus Rufinum III 4, PL 23, 460A: „Quis Bethleem de cubiculo fratris Eusebii furatus est epistolam laudatricem tuam? Cuius artificio et a cuius ministris in sanctae Fabiolae hospitio et viri christiani et prudentis Oceani, inventus est codex, quem illi numquam viderant". 
i poślubiła innego. Po jego śmierci zrozumiała swój błąd, nawróciła się $e^{51}$,wyznała publicznie swój grzech wobec papieża, duchowieństwa i wiernych w Wielką Sobotę w Bazylice Laterańskiej oraz podjęla publiczną pokutę:

„Któż by przypuszczal, że [...] przywdzieje wór, wyzna publicznie błąd i na oczach całego Rzymu przed dniem Paschy w bazylice należącej dawniej do Laterana, który został zabity mieczem cesarskim, stać będzie w rzędzie pokutników przed biskupem, przed kapłanami oraz całym płaczącym ludem, z rozwianym włosem, bladymi ustami, szorstkimi rękami i pochyloną nisko glową? Czy są grzechy, których by taki płacz nie oczyścir?"52.

Podjąwszy pokutę zmieniła swe życie, wycofała się z życia publicznego, swój rozległy majątek rozdała ubogim klasztorom, a nawet założyła w Rzymie pierwszy w dziejach szpital, w którym osobiście pielęgnowała chorych i karmila głodnych:

„Cały majątek, jaki posiadała - a byl bardzo duży i odpowiedni dla jej rodu podzielila i sprzedala, a uzyskane pieniądze przygotowała na użytek ubogich. Pierwsza ze wszystkich założyła voбoxoukĩov - szpital, w którym gromadziła chorych znalezionych na ulicy i pielęgnowała nieszczęśliwych, wycieńczonych chorobami i głodem. Czy mam tu opisywać różne nieszczęścia ludzkie: obcięte nozdrza, wydarte oczy, na wpół spalone nogi, sine ręce, opuchłe brzuchy, suche biodra, nabrzmiale nogi i robactwo kotłujące się w wyniszczonych, gnijących ciałach? Ile razy dźwigała na wlasnych ramionach cuchnących chorych, dotkniętych chorobą królewską! Ile razy obmywała ropiejące rany, na które kto inny nie mialby sił spojrzeć! Własnoręcznie karmiła i poiła żywe trupy [...].

Fabiola tak wielką biedakom umiala przynieść ulgę, iż wielu zdrowych między ubogimi zazdrościło chorym. A z podobną hojnością odnosiła się ona do duchownych, mnichów i dziewic. Ileż to klasztorów otrzymało wsparcie z jej zasobów! Iluż nagich złożonych na łożu boleści okryło odzienie Fabioli! Iluż potrzebujących wspierala chętnie i szybko w swej hojności!"s3.

Nie wystarczyła jej jednak sama Italia. W 394 r. wybrała się w podróż do Palestyny. Odwiedzila po drodze klasztory i miejsca święte, ofiarowując obfite dary. Przyjechala do Betlejem, by odwiedzić przebywających tu Hieronima, Paulę i Eustochium oraz oddać się pod ich kierunkiem gorliwemu studiowaniu Pisma świętego:

„Z jakimże zapalem, z jaką gorliwością studiowała Księgi święte! Przebiegała pisma Proroków, Ewangelie, Psalmy, jakby tym pragnęła głód zaspokoić. Zadawała pytania, odpowiedzi zaś chowała głęboko w swym sercu. A nie nasyciła się żądzą słuchania, lecz zdobywane wiadomości wzmagały jej ból i jakby dolewały

\footnotetext{
${ }_{51}$ Por. Epistula 77, 3, PL 22, 691, Czuj II 159-161.

52 Tamże 4, PL 22, 692, Czuj II 161.

53 Tamże 6, PL 22, 694, Czuj II 164-165.
} 
oliwy do ognia, tak zwiększała się jej żarliwość. Gdyśmy pewnego dnia trzymali w rękach Księgę Liczb Mojżesza i gdy mnie nieśmiało pytała, co by znaczyło tak wielkie nagromadzenie imion, dlaczego poszczególne pokolenia w różnych miejscach różnie się łączą, w jaki sposób prorok Balaam tak wyraźnie przepowiedział tajemnice Chrystusa, jak tego nie uczynil prawie żaden z Proroków - odpowiedziałem jak moglem i zdawało mi się, żem uczynił zadość jej pytaniu. Rozwijając więc książkę doszła do tego miejsca, gdzie jest opisany spis postojów, przez które naród po wyjściu z Egiptu doszedl aż do wód Jordanu. I gdy pytała o przyczyny i uzasadnienie poszczególnych postojów, co do niektórych wahałem się, co do innych nie miałem wątpliwości, a po największej części szczerze wyznawałem swą niewiedzę. Wtedy jeszcze bardziej zaczęła nalegać i jakby mnie nie wolno było nie wiedzieć tego, czego nie wiem, prosiła o wyjaśnienie, mówiąc, że zapewne nie jest godna tak wielkich tajemnic. Cóż więcej? Wymogła na mnie obietnicę a odmówić się wstydzilem - że napiszę dla niej dzieło na ten temat"54.

Musiała być filologicznie i teologicznie dobrze przygotowana do zadawania pytań, skoro na niektóre $\mathrm{z}$ nich Hieronim nie był w stanie natychmiast odpowiedzieć. Faktycznie na dwa postawione wówczas pytania odpowiedział jej dopiero później, przesyłając w 397 r. mistyczny i moralny komentarz do fragmentów Pentateuchu opisujących szaty najwyższego kapłana ${ }^{55}$, a w 399 r. mistyczne objaśnienie etapów wędrówki narodu wybranego od wyjścia z Egiptu do ziemi obiecanej ${ }^{56}$.

Fabiola jednak po rocznym pobycie w Betlejem powrócila do Rzymu w obawie przed nawałnicą zblizających się do Palestyny barbarzyńskich Hunów, zamieszkawszy w obcym domu. Po powrocie założyła razem z senatorem Pammachiuszem ksenodochium w Ostii ${ }^{57}$. Zmarła w 399 roku. Na jej pogrzeb wyległy wielkie tłumy wdzięcznych Rzymian. Przed śmiercią zawiadomiła wielu mnichów, by przybyli zabrać resztki jej majątku:

„W przewidywaniu przyszłości napisała do wielu mnichów ,żeby przybyli i uwolnili ją od wielkiego ciężaru, który ją dręczy, aby mogła z mamony niesprawiedliwości uczynić sobie przyjaciól, którzy by ja przyjęli do wiecznych przybytków. Przybyli, stali się jej przyjaciółmi. A ona zasnęła - tak jak tego chciała - i złożywszy wreszcie brzemię nie obarczona żadnym ciężarem odeszła do nieba. Jaki podziw miał Rzym dla żyjącej Fabioli, to okazało się po jej śmierci. Jeszcze nie wyzionęla ducha, jeszcze nie oddała Chrystusowi należącej do niego duszy, «a już wieść, przesłanniczka tak wielkiej boleści», zgromadzała na pogrzeb ludność całego miasta. Rozbrzmiewały Psalmy, a pozłacanymi dachami świątyń wstrząsało odbijające się echem w górze alleluja [...] gromadnie napłynęły, liczne rzesze towarzyszące jej

54 Tamże 7, PL 22, 695, Czuj II 165-166.

55 Por. Epistula 64, PL 22, 607-622, Czuj I 35-56.

${ }^{56}$ Por. Liber exegeticus de XLII mansionibus Israelitarum in deserto = Epistula 78, PL 22, 698724, Czuj II 170-209.

57 Por. Epistula 77, 10, PL 22, 697, Czuj II 169: „Cały świat dowiedział się prawie równocześnie o założeniu ksenodochium $w$ porcie rzymskim. Brytania dowiedziała się o tym w lecie, a Egipcjanie i Partowie już na wiosnę". 
pogrzebowi, a ulice, portyki i dachy wznoszące się w górę nie mogły pomieścić przyglądających się. Wtedy Rzym. zobaczył swój lud zebrany razem; wszyscy wzajemnie sobie pomagali w chwale pokutnicy"58.

Postać nawróconej i pokutującej Fabioli służącej ubogim już w starożytności była uosobieniem charytatywnej służebnicy, o której już Hieronim powiedzial, że „stała się chwałą chrześcijan, wzbudziła podziw u pogan, pozostawiła żałobę wśród ubogich, i stanowiła pociechę mnichów" ${ }^{\prime \prime 9}$. Nic dziwnego, że papież Pius XII przemawiając w Rzymie 21 V 1952 r. do lekarzy i pielęgniarek jej wlaśnie przykład przypomnial ${ }^{60}$.

$\mathrm{Z}$ domem Marceli bardzo mocno była związana piękna dziewica Asela ${ }^{61}$, o której życiu informuje nas w swoich listach $(24,45,65)$ św. Hieronim ${ }^{62}$ oraz Palladiusz i Martyrologium Rzymskie ${ }^{63}$. Najpierw (r. 384) w liście do Marceli, gdy Asela miała ok. 50 lat $^{64}$, a później (r. 397) już z Betlejem w liście do Pryncypii ${ }^{65}$ stawial ją Hieronim za wzór studiowania Pisma św. i ascezy dla młodych dziewic. Jej narodzenie (ok. 344 r.) poprzedzone było wizją, w której ojciec oglądał jej duszę jako świętej dziewicy w czystym szklanym naczyniu. Nic więc dziwnego, że ta już $w$ dziesiątym roku życia poświęciła się prywatnie Bogu $^{66}$; gdy zaś ukończyła lat 12 , potajemnie sprzedała swój złoty naszyjnik,

58 Tamże, 77, 11, PL 22, 697, Czuj II 169-170.

59 Tamże 77, 2, Czuj II 158-159, PL 22, 691: „laudem christianorum, miraculum gentilium, luctum pauperum, solatium monachorum".

60 Por. Discorso ai sanitari ed infermieri di Roma, w: Pio XII, Discorsi e radiomessaggi, XIV, Città del Vaticano 1953, 155-156.

${ }^{61}$ Por. Jenal, Italia ascetica, s. 53-55; BS II 501-503 (G.B. Proja); DHGE IV 915-917 (D. Gorce); ECat II 105-106 (C. van Hulst); Vies des Saints, XII, Paris 1956, 213-219; LThK I 1061 (M.B. Stritzky); PLRE I 117.

62 Por. Epistula 24, PL 22, 427-428 lub CSEL 54, 214-217, Czuj I 165-167; Epistula 45, PL 22, 480-484 lub CSEL 54, 323-328, Czuj I 251-255; Episula 65, 2, PL 22, 624 lub CSEL 54, 619, Czuj II 58-59.

${ }^{63}$ Por. Historia Lausiaca 41, 4, ed. G.J.M. Bartelink (1974) s. 212, tłum. S. Kalinkowski, ŹM 12, 187-188: „W Rzymie spotkałem świętą dziewicę Asellę, która swe długie życie spędzila w klasztorze; była kobietą niezwykle skromną i z pokorą znosiła życie we wspólnocie"; Martyrologium Romanum (6 XII), tłum. P. Turbak (Martyrologium Rzymskie, Kraków 1967) s. 347: „W Rzymie świętej Aselli, panny, która według św. Hieronima ubłogosławiona od żywota matki prowadziła aż do starości życie w postach i modlitwach".

64 Por. Epistula 24, 1, PL 22, 427, Czuj I 165: „Proszę nie czytaj tego listu - gniewa się bowiem, gdy się ją chwali. Zechciej przeczytać go raczej tym bardzo młodym, by jej przykladem kierując się w postępowaniu, brały jej doskonałe życie za wzór".

${ }^{65}$ Por. Epistula 65, 2, PL 22, 624, Czuj II 58-59: „Masz tam, jako wzory w studiowaniu Pisma oraz uświęcaniu umysłu i ciała, Marcelę i Aselę. Niechaj jedna z nich zawiedzie cię przez zieleniejące łąki i rozmaite kwiaty ksiąg Bożych do tego, który mówi w pieśni: „Jam kwiat polny i lilia padolna" (Pnp 2,1). Druga, która sama jest kwiatem Pana, niechaj wraz z tobą stanie się godna tych słów: „Jako lilia między cierniami, tak przyjaciółka moja między córkami” (Pnp 2, 2).

${ }_{66}$ Por. Epistula 24, 2, PL 22, 427, Czuj I 165. 
kupiła ciemną szatę pokutną i zamknęła się w małej celi, w której oddawała się postom, umartwieniom i modlitwie, sypiając we włosiennicy na gołej ziemi i wychodząc z niej tylko dla odwiedzenia grobów męczenników. Jej ascetyczną postawę tak charakteryzuje Hieronim:

„[...] tak skromnie się zawsze zachowywala i ukrywała się w tajnikach swego mieszkania, że nigdy kroku nie zrobiła na oczach ludzi, nigdy z mężczyzną nie rozmawiała $i$ - co więcej jeszcze godne podziwu - siostrę dziewicę raczej kochała, niż widywała. Pracowała rękami swymi, wiedząc, że jest napisane: «Kto nie pracuje, niech też nie je» $(2 T e s 3,10)$. Z Oblubieńcem rozmawiała albo się modląc, albo śpiewając psalmy; do grobów męczenników niewidzialna prawie śpieszyła i gdy się cieszyła ze spełnienia swego zamiaru, to radość jej powiększało to, że nikt jej nie poznał. Gdy przez caly rok nieustannie praktykowała posty, po dwa i trzy dni w nich trwając, dopiero w Wielkim Poście okrętu swego rozwijała żagle, przez wszystkie tygodnie radosne ukazując oblicze. I - co zapewne wyda się ludziom nie do wiary, a co możliwe jest przy Boskiej pomocy - tak doszła do lat pięćdziesięciu życia, i ani nie dolegal jej żołądek, ani nie sprawiały cierpień zaniedbane wnętrzności, ani sucha ziemia nie znużyła spoczywających na niej członków, ani włosiennicą podrapana skóra nie okrywała się jakowymś cuchnącym brudem, ale zdrowa, na ciele, a zdrowsza na duszy, samotność uważała za rozkosz i w hałaśliwym mieście znajdowała pustelnię klasztorną [...].

[Marcello], ty też na własne oczy widziałaś na kolanach wielbłądzią twardość, która wytworzyła się od częstej modlitwy owego świętego ciała.

Ja mówię o tym, co wiem. Nic nad surowość jej życia weselszego, nic nad wesolość surowszego, nic nad śmiech smutniejszego, nic nad smutek przyjemniejszego. Bladość malująca się na obliczu wskazuje na powściągliwość, a nie trąci ostentacją. Postawa milcząca, a milczenie pełne wymowy, chód ani prędki, ani powolny. To samo zawsze odzienie, niedbała staranność, a w nieeleganckiej szacie objawia się sama wytworność bez dbalości o wytworność"67.

Pozostała cichą, pokorną, przeważnie milczącą i skromnie ubraną kobietą, która budziła szacunek u wszystkich: dziewic, wdów, mężatek, a nawet duchownych. Dużym szacunkiem i zaufaniem darzył ją również św. Hieronim, mimo swego wrodzonego krytycyzmu do kobiet. Kiedy bowiem w sierpniu 385 r. rozgoryczony i zdegustowany intrygami i różnymi oskarżeniami opuszczał Rzym, do niej właśnie napisal jedyny list (45), w którym się usprawiedliwiał i prosił o modlitwę, mając nadzieję, że zostanie zrozumiany. Nie wiemy bliżej, w jakim stopniu Asela uczestniczyła w życiu naukowo-ascetycznym rzymskiego klubu awentyńskiego, lecz musiała to czynić skoro Hieronim stawiał ją za wzór w studiowaniu Pisma św. ${ }^{68}$, a w liście do niej skierowanym prosi ją nie tylko o pamięć i modlitwę, lecz także o pozdrowienie uczęszczających tam współtowarzyszek:

\footnotetext{
${ }^{67}$ Epistula 24, 3-5, PL 22, 427-428, Czuj I 166-167.

68 Por. wyżej nota 65.
} 
„Pozdrów Paulę i Eustochium - czy świat chce czy nie chce, moje są w Chrystusie pozdrów matkę Albinę i siostry - Marcelę, Marcelinę, a także i świętą Felicytę [...]. Pamiętaj o mnie, przykładzie czystości i ozdobo dziewictwa, a fale morskie poskramiaj swymi modlitwami",69.

Nie wiemy również, kiedy umarła, zapewne po r. 405, kiedy to Palladiusz spotkal ją posuniętą w latach jeszcze w Rzymie i zanotowal: „w Rzymie spotkałem świętą dziewicę Aselę, która swe długie życie spędziła w klasztorze"70.

Drugim arystokratycznym chrześcijańskim domem w Rzymie, obok pałacu Marceli na Awentynie, była rodzina Pauli, z którą św. Hieronima połączyły dość silne więzy przyjaźni. Do niej to właśnie i do jej rodziny skierował aż 7 listów. Rodzina ta była zaprzyjaźniona $\mathrm{z}$ domem Marceli, co poświadcza prowadzona między nimi korespondencja ${ }^{71}$. Paula ${ }^{72}$ więc obok Marceli, to drugi ważny filar damskiego klubu arystokratek rzymskich na Awentynie.

Urodziła się w Rzymie w 347 r. w patrycjuszowskiej chrześcijańskiej rodzinie, z ojca Rogatusa, pochodzenia greckiego i matki Blezyli, wywodzącej się ze Scypionów i Grakchów. ${ }^{73}$. W 15 roku życia (362) poślubiła poganina Toksocjusza, nazywanego także Juliuszem, mającego wywodzić się z mitycznych Juliuszów $^{74}$, który jednak nie przeszkadzal jej w wyznawaniu chrześcijaństwa. $\mathrm{Z}$ ich związku urodzity się 4 córki (Blezyla, Paulina, Rufina, Eustochium, nazywana także Julią, oraz syn Toksocjusz ${ }^{75}$. Paula darzona ogólnym szacunkiem, opływała w bogactwo, miała do dyspozycji wspaniały pałac, stroje, liczną służbę, a gdy udawała się z wizytą do towarzyszek, noszona była przez eunu-

${ }^{69}$ Epistula 45, 7, PL 22, 484, Czuj I 255: „Memento mei, exemplum pudicitiae et virginitatis insigne, fluctusque maris tuis precibus mitiga".

70 Por. wyżej nota 63.

71 Por. Epistula 46 (Pauli i Eustochium do Marceli), PL 22, 483-492, Czuj I 256-269.

72 Por. Epistula 108, PL 22, 878-906, Czuj II 414-453; F. Lagrange, Histoire de Sainte Paule, Paris 1867; R. Genier, Sainte Paule, Paris 1917; Vies des Saints, I, Paris 1935, 521-527; G. Del Ton, Santa Paola Romana, Milano 1950; BS X 123-136 (G. Del Ton); DIP VI 1098 (J. Gribomont); ECat IX 697-698; LThK ${ }^{2}$ VIII 204-205 (U.M. Fasola); PLRE I 674-675.

73 Por. Epistula 108, 1 i 3, PL 22, 878-880, Czuj II 414 i 416.

74 Por. tamże 4, PL 22, 880, Czuj II 417: „Z takich więc zrodziła się przodków, a zlączyła się węzłem małzeńskim $z$ Toksocjuszem, który pochodzi z wysokiego rodu Eneasza i Juliuszów. Stąd też córka jej Eustochium, dziewica Chrystusowa - nazywa się Julia, a samo imię Juliusz wywodzi się od wielkiego Julusa".

${ }^{75}$ Por. tamże: „Takich miała przodków, jak powiedziałem. Cenił ją przede wszystkim mąż za jej skromność i za to, że urodziła mu dzieci, cenili ją krewni, ceniło ją cale miasto. Miala pięcioro dzieci: Blezylę, po której śmierci pocieszałem ją w Rzymie; Paulinę, która uczyniła Pammachiusza, swego świątobliwego, godnego podziwu małzonka, dziedzicem swego ślubu i swego mienia; po jej zgonie napisałem dla niego krótką książeczkę; Eustochium, która obecnie w miejscach świętych jest cennym klejnotem Kościoła i chlubą dziewic; Rufinę, której przedwczesny zgon wstrząsnął do głębi pobożną duszą matki, i Toksocjusza, po którym już przestała rodzić. $Z$ tego można wnioskować, że nie chciała dłużej spełniać obowiązków małżeńskich, ale była posłuszna mężowi, który pragnął mieć męskiego potomka". 
chów wspaniałą wykładaną złotem lektyką. Mimo to pozostawała miłosierna i szczodrobliwa, uprzejma i czysta moralnie (matronalis castitas). Podziwiała dziewice i wdowy, gromadzące się w pałacu Marceli w celach ascetyczno-intelektualnych, gdzie zaczęła uczęszczać. Zażyłość z klubem arystokratek na Awentynie pogłębiła się po śmierci męża (379), kiedy to jeszcze bardziej zwróciła się ku Bogu ${ }^{76}$. Paula, podobnie jak Marcela, postanowiła pozostać wdową, zmienić swoje życie i więcej czasu poświęcić Bogu. Co więcej, z najbardziej związaną uczuciowo córką Eustochium udala się do Marceli, prosząc ją o włączenie do awentyńskiego towarzystwa, co zostało przyjęte przez członkinie $z$ dużym entuzjazmem. Eustochium pozostała przez pewien czas w szkole Marceli, oddając się intensywnie ćwiczeniom ascetycznym i poszerzaniu swej wiedzy religijnej na organizowanych tu spotkaniach. Paula natomiast musiała się zająć osieroconą rodziną, lecz również swój dom zaczęła urządzać na wzór domu Marceli: przyjmować w nim i na równi traktować krewnych, klientów, służbę, dzielić się z nimi swoim rozległym majątkiem, modlić się wspólnie, prowadzić rozmowy religijne, medytować Pismo św. i spełniać uczynki miłosierdzia, zwłaszcza wobec chorych i ubogich, których sprowadzala z miasta; sama usługiwała im ubrana w ubogą ciemną suknię:
„Wszystkie prawie bogactwa, jakie zawieral jej dom obszerny, szlachecki, niegdyś bardzo zasobny, zostały teraz wydane na ubogich. Czy mam mówić o tym uspo- sobieniu laskawym dla wszystkich i o tej dobroci obejmującej nawet tych, których nigdy nie widziała? Kto $z$ umierających biedaków nie był owinięty jej szatami, kto $z$ chorujących obłożnie nie uzyskał od niej pomocy? Szukała ich starannie po całym mieście i uważała to za stratę, jeśli ktoś ułomny i łaknący otrzymał pożywienie od kogo innego. Ogałacała dzieci, a gdy ją krewni karcili, mawiała, że im zostawiła większe dziedzictwo w postaci milosierdzia Chrystusowego"77.

Dawnym zwyczajem, jako właścicielka jednego $z$ najbogatszych domów rzymskich, przyjmowała również gości $z$ wyższych sfer, w tym również zagranicznych, chociaż ich liczbę starała się teraz ograniczyć. Kiedy w 382 r. przyjechał na synod do Rzymu Hieronim razem $z$ biskupem Antiochii, Paulinem i biskupem Salaminy, Epifaniuszem, gościła ich u siebie, a 74-letni Epifaniusz, uczeń Hilariona i założyciel jednego $z$ monasterów w Palestynie, nawet u niej zamieszkał. Z zapałem słuchała ich opowiadań o pustelniczym i monastycznym żciu na Wschodzie, i niepomna swych dzieci, rodziny i domu, postanowiła opuścić ojczyznę i ,udać się do pustelni Antonich i Pawłów"78. Gdy Hieronim, zaproszony przez Marcelę, stał się duchowym kierownikiem „wieczernika" na Awentynie, ona przykładnie i gorliwie ze swymi córkami, zwlaszcza

\footnotetext{
${ }^{76}$ Por. tamże 5, PL 22, 880, Czuj II 417: „Gdy mąż umar1, tak go opłakiwała, że prawie sama bliska była śmierci, a tak się nawróciła do służby Pańskiej, że wydawało się, iż pragnęła jego smierci".

${ }^{77}$ Por. tamże, PL 22, 880-881, Czuj II 418.

${ }^{78}$ Por. tamże 6, PL 22, 881, Czuj II 418.
} 
Eustochium i owdowiałą Blezylą, uczęszczała na jego ascetyczne i biblijne konferencje. Znała dobrze język grecki i laciński. Aby jeszcze lepiej czytać i zrozumieć Stary Testament, nauczyła się jeszcze hebrajskiego, tak ze byla $\mathrm{w}$ stanie śpiewać psalmy $\mathrm{w}$ języku oryginalnym. W porównaniu z Marcelą wolała nie tyle naukowo analizować tekst biblijny, co odczytywać go i gustować w jego sensie mistycznym. W tym duchu Hieronim napisał dla niej w $384 \mathrm{r}$. list o etymologii i mistycznym znaczeniu hebrajskich liter, rozpoczynających akrostychicznie wersety w 118 psalmie, będący odpowiedzią na postawione przez nią na Awentynie pytanie: „Bardzo gorliwie dopytywałaś się, co by znaczyły litery hebrajskie wplecione w ten psalm, który czytaliśmy", list zaś kończył słowami:

„Pozdrów Blezylę i Eustochium, moje uczennice (tirunculae nostrae), pozdrów Felicjanę, cieszącą się prawdziwym dziewictwem ciała i duszy, pozdrów pozostałe dziewice i swój rodzimy kościół [...]. Jeśliby nasza najpracowitsza (фı Marcela chciala otrzymać kopię tego listu, użycz jej i pamiętaj o mnie w modlitwie" ${ }^{79}$.

Po śmierci swej owdowiałej córki Blezyli (384 r.), spowodowanej chorobami i umartwieniami, swój matczyny ból ofiarowała Chrystusowi. Hieronim skierował do niej wówczas list konsolacyjny, w którym tak ją scharakteryzował:

„Dotychczas rozmawiałem z tobą tak, jakbym spotkał jaką́s chrześcijankę z thumu. Teraz zaś, gdy wiem, żeś się całkowicie wyrzekła świata, a po odrzuceniu i podeptaniu rozkoszy oddajesz się codziennie modlitwie, postom $i$ czytaniu [...] gdy caly majątek alboś ubogim rozdała albo synom oddała" ${ }^{80}$.

W tym czasie również napisał (384) obszerny list do drugiej córki Pauli, do Eustochium, o zachowaniu dziewictwa ${ }^{81}$.

Kiedy po śmierci papieża Damazego (11 XII 384) wskutek różnorodnych intryg i oskarżeń, Hieronim wyjechał w sierpniu 385 r. na Wschód, by osiąść w Betlejem, Paula w żałobie po Blezyli poczuła się opuszczona. Postanowila wyjechać i w kraju Jezusa, pod duchowym kierownictwem Hieronima, założyć kobiecą wspólnotę klasztorną na wzór rzymskiego „wieczernika” na Awentynie. Po zimowym uspokojeniu się morza Paula zabrała ze sobą umiłowaną Eustochium i kilka dziewic, oraz udała się przez Ostię na Wschód. W Ostii pożegnała się z rodziną: $z$ Pauliną wydaną za Pammachiusza oraz oddanymi im pod opiekę dorastającą Rufiną i malym jeszcze Toksocjuszem, przekazując im i ubogim swój majątek. ${ }^{82}$. Podróżując przez Antiochię i Seleucję, zrewizytowała

${ }^{79}$ Epistula 30, 14, PL 22, 444, Czuj I 189; cały list, PL 22, 441-445,Czuj I 185-189, pytanie zaś 30, 1, PL 22, 442, Czuj I 186.

${ }^{80}$ Epistula 39, 5, PL 22, 472, Czuj I 235; cały list: PL 22, 465-473, Czuj I 226-239.

81 Epistula 22, PL 22, 394-425, Czuj I 110-162.

82 Por. Epistula 108, 6, PL 22, 881, Czuj II 418-419. 
po drodze biskupa Paulina i biskupa Epifaniusza na Cyprze, u którego jakiś czas się zatrzymała, oraz odwiedziła znajdujące się tam klasztory. Potem przez Syrię, Fenicję i Egipt dotarła do Palestyny, gdzie w Jerozolimie witana była przez samego prokonsula ${ }^{83}$, a zwiedziwszy miejsca związane z Chrystusem osiadła w Betlejem, prowadząc surowe życie ascetyczne ${ }^{84}$. W mieście narodzin Chrystusa początkowo zamieszkała w ciasnej gospodzie, a potem ufundowała w ciągu 3 lat monaster dla Hieronima i jego towarzyszy, ksenodochium dla pielgrzymów odwiedzających Ziemię świętą oraz zorganizowała kobiecą wspólnotę religijną według reguły Pachomiusza, poświęcając ją św. Katarzynie Aleksandryjskiej. Podobnie jak na Awentynie, razem modliły się, śpiewały psalmy, uczyły się ich na pamięć, a także innych passusów Pisma św., słuchały konferencji biblijnych św. Hieronima, podejmowały wiele postów i umartwień. Na program dnia i życia tej wspólnoty, obok lokalnych tradycji monastycznych egipskich i syryjskich, wpłynęły niewątpliwie atmosfera i zajęcia ascetycznointelektualne awentyńskiego „wieczernika”. A oto ich szczegółowy opis w relacji Hieronima:

„Po założeniu klasztoru męskiego, który oddała w zarząd mężczyznom, podzieliła ogromny zastęp dziewic, które zgromadzila z różnych prowincji (były tam zarówno szlachcianki, jako też dziewczęta średniego i niższego pochodzenia), na trzy grupy klasztorne, ale tylko tak, że rozdzielone w pracy i posiłku, łączyły się na śpiewanie Psalmów i na modlitwy. Po odśpiewaniu «Alleluja», którym to hasłem zwoływane były na zbiórkę, żadnej nie wolno było próżnować. Sama Paula przychodząc pierwsza lub jedna z pierwszych zawstydzala inne, a do pracy zachęcała je przykładem - nie groźbą. Rano o godzinie trzeciej, szóstej i dziewiątej, wieczorem i o północy śpiewały po kolei Psalmy. Każda siostra musiala znać Psalmy, a także uczyć się codziennie czegoś z Pisma świętego.

Tylko w niedzielę szły do kościoła, przy którym mieszkały, a każdy oddział postępował za własną matką. Następnie, wracając w taki sam sposób, zabierały się do dalszej pracy i robiły odzienie - dla siebie lub innych. Jeśli która należała do szlachetnego rodu, nie pozwalano jej mieć towarzyszki ze swego domu, nie chcąc, aby pomna minionych postępków odświeżała i ponawiała wskutek częstych rozmów dawne błędy swawolnego dzieciństwa. Jeden był strój wszystkich; płótna używały tylko do obtarcia rąk. Od mężczyzn oddzielone były tak dalece, że nie miały kontaktu nawet $z$ eunuchami, by nie dawać żadnej okazji złośliwości języka, która ma zwyczaj szarpać świętych na pociechę we własnych upadkach.

Jeśli która zbyt późno przychodziła na Psalmy albo była opieszała w pracy, Paula usilowała oddziaływać różnymi sposobami. Na popędliwą - pochlebianiem, na niecierpliwą - lajaniem, naśladując owe slowa Apostola: «Czegóż chcecie? Czy

${ }^{83}$ Por. Epistula 108, 9, PL 22, 883, Czuj II 421: „wkroczyla do Jerozolimy, miasta o trzech nazwach: Jebus, Salem, Jeruzalem, które później przez Aeliusza Hadriana zostało wskrzeszone $z$ ruin i popiołów jako Aelia. A gdy prokonsul Palestyny, który znał jej rodzinę bardzo dobrze, wysławszy naprzód woźnych, kazał przygotować dla niej mieszkanie w pałacu, ona wybrała skromną celkę".

${ }^{84}$ Opis zwiedzonych miejsc, por. Epistula 108, 7-15, PL 22, 882-892, Czuj II 419-431. 
mam do was przybyć z rózgą, czy też z miłością i w duchu łagodności?» (1Kor 4, 21). Nie pozwalała, by którakolwiek miała coś poza pożywieniem i odzieniem, stosownie do słów Pawła: «Mając żywność i czym się przyodziać, na tym poprzestawajmy». Nie chciała dopuścić do tego, żeby przyzwyczajenie posiadania zbyt wiele spowodowało chciwość, która nie daje się zaspokoić żadnymi dostatkami i o ile więcej ma, o tyle więcej pożąda i nie zmniejsza się ani przez dosyt, ani przez niedostatek. Sprzeczające się dziewczęta jednala łagodnymi słowami. Swawolne ciało ich ujarzmiała częstymi, zdwojonymi postami woląc, by cierpial żołądek, niż szkodę poniósł umysł. Gdy zobaczyła którąś zbyt starannie ubraną, zmarszczeniem czola i zasmuconym obliczem karciła błądzącą mówiąc, że czystość ciała i odzienia jest nieczystością duszy. Mawiala też, że brzydkie, nieprzyzwoite słowo nie powinno nigdy wyjść z ust dziewiczych, bo to znak dający poznać lubieżne myśli, znak, który pokazuje na zewnątrz grzechy znajdujące się wewnątrz czlowieka. Jeśli zauważyła, że któraś ma zbyt długi język, jest gadatliwą, zuchwałą i lubi klótnie, a nie chce się mimo częstych napomnień nawrócić, kazała jej modlić się przed drzwiami do jadalni wśród ostatnich sióstr i poza miejscem zgromadzenia, a pokarm spożywać osobno, zeby wstyd skłonil ją do poprawy, skoro nie dokonała tego nagana. Kradzież potępiała, jak świętokradztwo, a przewinienie, które wśród ludzi świeckich uchodzi za lekkie lub za nic, w klasztorze było - jej zdaniem - bardzo ciężkim występkiem"85.

Był to już praktycznie prawdziwy żeński klasztor, ze swoim programem dnia codziennego, wypełniony ćwiczeniami ascetycznymi - umartwieniami i postami, obok których, podobnie jak na rzymskim Awentynie, ważne miejsce zajmowala lectio divina - czytanie i medytowanie Pisma świętego.

Przez cały zresztą czas Paula utrzymywała kontakt listowny z Marcelą z Rzymu. Być może za sugestią św. Hieronima razem z córką Eustochium wysłały do niej piękny list (46), w którym zapraszały ją, by przeniosła się do ziemi Chrystusa. Paula bowiem nadal czuła się ze swą wspólnotą uczennicą Marceli i jej towarzyszek:

„Żałosne wznosimy modły i pragnienia nasze nie tyle płaczem, ile okrzykami wyrażamy, by nasza Marcela tu przybyła, i by tu łagodna, miła i nad wszelki miód i slodycz słodsza nie była sztywna i smutnie nie marszczyła czola wobec tych, które swą lagodnością do podobnego trybu życia nakłoniła [...]. Może w myśli zganisz nas, że nie trzymamy się porządku Pisma, lecz tak na chybil trafil i co w drogę wejdzie, omawiamy tu bez porządku i powierzchownie [...]. Nawet litery wyczuwają, że sprzeciwiasz się temu, co mówimy [...]. O kiedyż nadejdzie ów czas, gdy zdrożony posłaniec przyniesie wieść, że nasza Marcela przybiła do wybrzeży Palestyny, a całe chóry mnichów, całe orszaki dziewic radosną wrzawę czynić będą? Wyobrażamy sobie, że już wybiegamy na spotkanie i nie czekając na pojazd biegniemy w podnieceniu. Trzymać cię będziemy za ręce, patrzeć w twoje oblicze i z trudem wyrwiemy się z tyle pożądanych objęć. Czyż nie nadejdzie ten dzień, który pozwoli nam wejść razem do groty Zbawiciela"86. 
Marcela jednak nie dała się namówić i nie przybyła do Betlejem. Przyjechała natomiast $z$ jej awentyńskiego towarzystwa razem $z$ innymi, Fabiola, ale po roku $\mathrm{z}$ obawy przed najazdem Hunów wróciła do Rzymu. Paula wkrótce potem ciężko zachorowała, martwiąc się, ,"gdy jej donoszono o szkodach majątkowych i zniszczeniu całej ojcowizny [...] gdy jej pisano o ciężkich chorobach dzieci, a przede wszystkim jej Toksocjusza, którego najbardziej miłowała"87. Pożegnana przez miejscowe duchowieństwo zmarła 26 stycznia 406 roku, w obecności córki Eustochium, co wzruszająco opisał Hieronim:

„Zapadla w najciężzzą niemoc i zaiste znalazła to, czego sobie życzyła, opuściła nas, aby pełniej złączyć się z Panem. W czasie choroby wystąpiła w tym piękniejszym świetle wobec wszystkich miłość córki Eustochium ku matce. Sama bowiem siedziała przy jej lóżku, trzymała wachlarz, podtrzymywała glowę, podkladała poduszkę, rozcierala ręką nogi, okładała żołądek, przyrządzała miękką pościel, chłodzila gorącą wodę, przykładała ręcznik, uprzedzała obowiązki wszystkich służących i cokolwiek by inna uczyniła, uważala to za pozbawienie siebie nagrody. Z jakimiż ona modlami, z jakim płaczem i wzdychaniem biegała od chorej matki do groty Pańskiej modląc się o to, aby nie została pozbawiona jej obecności, by wraz z nią umarła, by poniesiono ją na tych samych marach! [...].

Przy jej śmierci byli obecni biskupi z Jerozolimy i innych miast i niezliczone mnóstwo kapłanów niższego stopnia oraz lewitów. Cały klasztor napelnił się chórem dziewic i mnichów. Ona zaś, gdy usłyszała wezwanie Oblubieńca: «Wstań, pójdź, najbliższa moja, piękna moja, gołębico moja, bo oto zima przeminęla, deszcz odszedł sobie» (Pnp 2, 10-11) - z weselem odpowiedziała: «Kwiaty ukazały się na ziemi, nadszedł czas ścinania» (Pnp 2, 12) i «Wierzę, iż oglądać będę dobra Pańskie w ziemi żyjących» (Ps 26, 13)" ${ }^{\prime 8}$.

Równie uroczysty był pogrzeb Pauli, w którym wzięło udział miejscowe duchowieństwo z biskupami, mnisi i mniszki ze wspólnoty betlejemskiej, a także thumy ubogich, wspieranych przez nią za życia. Zarówno w czasie pogrzebu, jak i po nim śpiewano Psalmy w języku łacińskim, greckim i syryjskim $^{89}$. Pochowano ją w Bazylice Bożego Narodzenia. Związany z nią emocjonalnie Hieronim ułożył napisy nagrobne ${ }^{90}$, przypominające, że zmarła w 56 roku życia, po 20-letnim pobycie i działalności w Betlejem ${ }^{91}$.

Warto na koniec przyjrzeć się ascetycznej sylwetce Pauli, która bez wątpienia wiele wyniosła $z$ awentyńskiej szkoły Marceli. Cechowała ją, mimo arystokratycznego pochodzenia, wielka pokora i skromność, umartwienie i wprost katowanie wlasnego ciała, dbałość o czystość ducha, by nie było pod tym

\footnotetext{
${ }^{86}$ Epistula 46, 1, 3, 4, 13, PL 22, 483, 485, 492, Czuj I 256, 258, 259, 268.

87 Epistula 108, 18, PL 22, 895, Czuj II 437.

${ }^{88}$ Epistula 108, 28-29, PL 22, 904, Czuj II 449-450.

${ }^{89}$ Por. Epistula 108, 30, PL 22, 905, Czuj II 451.

${ }^{90}$ Por. Epistula 108, 34, PL 22, 906, Czuj II 453.

${ }^{91}$ Por. Epistula 108, 35, PL 22, 906, Czuj II 453. O kulcie sw. Pauli zob. G. Del Ton, BS X 135136; o jej ikonografii M.Ch. Celetti, tamże s. 136.
} 
względem nawet jakichkolwiek podejrzeń. Wrażliwa na ubogich i potrzebujących zaciągała nawet długi, by nie odmówić im jałmużny. Zachowywała posty, którymi dręczyła swoje ciało. Kiedy Hieronim jako jej mistrz duchowy, wzywał ją do umiaru, ona - jak sam się skarży - pozostawała na jego wezwania ghucha i uparta. Mimo tej siły ducha, tęskniła za dziećmi, zwłaszcza wtedy, kiedy dowiadywała się o ich chorobach, nierzadko się załamywała, tym bardziej, ze sama zaczęla ciężko chorować:

„Ona, która w pogardzie dla pokarmu tak wielki okazywała upór, w smutku byla miękka i załamywała i się z powodu śmierci swoich bliskich, zwłaszcza dzieci - bo, ciągle żyła w niebezpieczeństwie śmierci i męża, i dzieci. Choć kładła znak krzyża na usta i piersi i znakiem tym usilowała zlagodzić ból macierzyński, uczucie bralo górę i serce matki budziło smutek w szczerze wierzącym umyśle; zwycięzając duchem, ulegała słabości ciala, bo choroba raz się jej uczepiwszy, nie opuszczała jej przez długi czas i nam sprawiała niepokój"”2.

Zgodnie jednak $\mathrm{z}$ tradycją wyniesioną ze szkoły na Awentynie, dużo miejsca i czasu poświęcała czytaniu, komentowaniu i medytowaniu Pisma św., a czyniła to pod kierunkiem św. Hieronima, stawiając mu duże wymagania, który tak o tym wspomina:

„Pismo umiała na pamięć, a kochając historię świętą, którą nazywała podwaliną prawdy, doszukiwala się w slowach Pisma raczej duchowego ich sensu i nim karmiła swą duszę. Wszak zmusiła mię, bym kierował lekturą Starego i Nowego Testamentu jej i córki. Wymawiając się przez skromność, dopiero na natarczywe i częste żądanie zgodzila się uczyć tego, czegom się nauczyl nie od siebie samego, to jest od najgorszego nauczyciela, jakim jest pycha, lecz od sławnych męzóo kościelnych. Jeśli kiedy wahałem się i wyznawalem szczerze, że czegoś nie wiem, nie chciała bynajmniej ustąpić, ale ciągłym pytaniem zmuszała mnie do wskazania, które spośród licznych i roztropnych wyjaśnień wydaje mi się bardziej prawdopodobne. Powiem coś nadto, co zazdrośnikom wyda się może. niewiarogodne: Chciala się uczyć języka hebrajskiego, którego ja od młodości z wielką pracą i trudem nauczyłem się częściowo i w niestrudzonym rozważaniu nie opuszczam go, aby nie stracić tego, czegom się nauczył. Opanowała ten język do . tego stopnia, że śpiewała Psalmy po hebrajsku i oddawała mowę bez żadnej właściwości języka łacińskiego"93.

Tak oto charakteryzował Hieronim w pośmiertnym epitafium bardzo bliską sobie Paulę, która „nad Rzym przeniosła Betlejem, a zlotem błyszczące pałace zamienila na lichą lepiankę z gliny" "94, tę „przedziwną kobietę", którą wszyscy podziwiali, a po jej odejściu opłakiwali ${ }^{95}$. W charakterystyce tej jest niewątpliwie wiele retoryki i przesady, właściwych zresztą dla epitafiów.

\footnotetext{
92 Epistula 108, 21, PL 22, 898, Czuj II 442.

93 Epistula 108, 27, PL 22, 902, Czuj II 448.

94 Epistula 108, 1, PL 22, 878, Czuj II 414.

95 Por. Epistula 108, 2, PL 22, 879-880, Czuj II 415-416.
} 
Kolejną postacią związaną z Awentynem była trzecia córka Pauli i Toksocjusza - Eustochium, umiłowana duchowa córka Hieronima. Głównym źródlem informacji o niej są listy św. Hieronima, zwłaszcza te, których sama jest adresatką $(22,31,108)^{96}$. Urodziła się ok. 367 r. w patrycjuszowskiej rzymskiej rodzinie. Pierwsze lata dzieciństwa i młodości spędziła wygodnie w arystokratycznym domu, a dopiero po śmierci ojca (379) razem z matką zwróciły się całkowicie ku Bogu i związały z klubem chrześcijańskich arystokratek. Wówczas to bardzo mocno zbliżyła się do matki, stając się jej najukochańszą córką i podzielając calkowicie jej uczucia religijne:

„Eustochium, która tak zawsze trzymała się matki i ulegała jej rozkazom, że nigdy bez niej nie kładła się na spoczynek, nigdy nie wychodziła, nigdy nie brała pokar$\mathrm{mu}$, ani jednego grosza nie miała własnego, lecz cieszyła się, że ojcowskie i matczyne skromne mienie matka rozdaje ubogim, a miłość ku rodzicielce uważała za największe dziedzictwo i bogactwo",97.

Kiedy w 382 r. duchowe kierownictwo nad tym arystokratycznym towarzystwem przejął przybyły ze Wschodu św. Hieronim i zaczął wygłaszać biblijne konferencje, razem z matką gorliwie na nie uczęszczały. Eustochium przylgnęla uczuciowo do Hieronima, pod jego wpływem zapewne złożyła ślub dziewictwa i przeniósłszy się na jakiś czas do domu Marceli ${ }^{98}$, stała się jego uczennicą. Nie tylko wyzbyła się arystokratycznych przyzwyczajeń i podjęła surowe praktyki ascetyczne, ale bardziej jeszcze zainteresowala się Pismem św., ucząc się nawet języka hebrajskiego, w czym konkurowała $z$ matką. Hieronim wyjątkowo ją polubil, nazywał ją „swoją duchową, Chrystusowi poświęconą córką" panią" ${ }^{100}$, a razem $\mathrm{z}$ jej siostrą Blezylą i matką Paulą - swoimi uczennicami"101, „kwiatami swojego rodu"102, bo „czy jest ktoś mężniejszy nad Eustochium, która bramy szlachetne i zarozumiałość rodu konsularnego skruszyła ślubem dziewictwa i w pierwszym mieście najprzedniejszy ród poddała pod jarzmo

\footnotetext{
${ }^{96}$ Por. Epistulae: 22, 66, 108, 143, 151, 153, 154; Palladius, Historia Lausiaca 41; zob. Eustochium, BS V 302-304 F. Caraffa); J. Cavallera, S. Jérôme, II, Louvain 1922, 56-63; J.N.D. Kelly, Hieronim, dz. cyt., 118-122; G. Del Ton, S. Paula, Milano 1950, 40-41, 67-75, 78-79, 96-106, 194-199, 200; Vies des Saints, IX, Paris 1950, 571-576; Catholicisme IV 720 (P. Antin); DHGE XVI 43-45 (D. Gorce); DPAC I 1304 (J. Gribomont) DSp IV 1715-1718 (P. Antin); LThK ${ }^{2}$ III 1205 (Beckmann); LThK $^{3}$ III 1017 (G. Disselham); PLRE I 312; DACL III 831; J. Steinmann, Saint Jérôme, Paris 1958, 137-142, 374; Jenal, Italia ascetica, s. 50-52.

${ }_{97}$ Epistula 108, 27, PL 22, 903, Czuj II 448.

98 Por. Epistula 127, 5, PL 22, 1090, Czuj III 279: „W jej [Marceli] domu wychowywała się Eustochium, ozdoba dziewictwa, i łatwo można ocenić, jaka musi być nauczycielka, skoro ma takie uczennice".

${ }^{99}$ Por. Epistula 108, 2, PL 22, 879, Czuj II 416.

100 Por. Epistula 22, 2 i 26, PL 22, 395-i 411, Czuj I 112 I 139.

101 Por. Epistula 30, 14, PL 22, 444, Czuj I 189; Epistula 45, 7, PL 22, 484, Czuj I 255.

102 Por. Epistula 54, 2, PL 22, 550, Czuj I 366; Epistula 66, 2, PL 22, 639, Czuj II 82.
} 
czystości?"103. Nazywa ją więc „cennym klejnotem Kościoła i chlubą dziewic"104, „ozdobą dziewictwa" ${ }^{105}$, a tuż przed wyjazdem z Rzymu napisał dla niej w 384 r. jeden $z$ najpiękniejszych w literaturze wczesnochrześcijańskiej traktatów o strzeżeniu dziewictwa w formie dłuższego listu $(22)^{106}, \mathrm{z}$ powodu którego naraził się na wiele plotek i fałszywych oskarżen ${ }^{107}$. Także Eustochium starała się odwdzięczyć za troskliwość mistrza, m.in. w $384 \mathrm{r}$. z okazji święta Apostołów Piotra i Pawła przesłała mu w darze z bilecikiem kosz z czereśniami, naramiennikami i gołąbkami, za co ten zrewanżował się krótkim listem objaśniającym symbolikę tych darów ${ }^{108}$.

Po opuszczeniu przez Hieronima w 385 r. Rzymu i udaniu się do Betlejem, jej matka Paula chcąc nadal być pod jego duchowym kierownictwem, postanowiła wyjechać za nim, zabierając ze sobą najukochańszą córkę Eustochium jako towarzyszkę w podróży. ${ }^{109}$ Kiedy dotarły do Betlejem, tu, w klasztorach żeńskich ufundowanych przez Paulę, podjęły wszelkie prace służebne:

„Wtedy nie mogły znieść brudów ulicznych; eunuchowie nosili je na rękach; $\mathrm{z}$ trudem przekraczały nierówny próg, jedwabna suknia była dla nich ciężarem, a słoneczny upal pożarem. Teraz zaniedbane, odziane w żałobne szaty i dzielne, jeśli zważymy ich przeszłość, albo napełniają oliwą lampy, albo rozpalają w piecu, zamiatają posadzki, obierają strączki, wiązki jarzyn wrzucają do wrzącego kotla, nakrywaja stoły, podają kubki, znoszą pokarmy, biegają na wszystkie strony. A razem z nimi mieszka liczny chór dziewic. Czy nie mogłyby nakazać innym wykonywania tego rodzaju poslug? Ale one nie chcą w pracy cielesnej stać niżej od tych, które same przewyższają mocą ducha"110.

Obie zachęcały i stymulowały Hieronima do pracy biblijnej. W odpowiedzi na to on w wielkiej przyjaźni dedykował im łaciński przekład Księgi Królewskiej, a samej Eustochium wstępy do 18 ksiąg Komentarza do Izajasza $a^{111}$ oraz do 14 ksiąg Komentarza do Proroka Ezechiela ${ }^{112}$ i kilkunastu innych komenta-

${ }^{103}$ Epistula 66, 3, PL 22, 640, Czuj II 83.

104 Epistula 108, 4, PL 22, 880, Czuj II 417.

105 Epistula 127, 5, Czuj III 279, PL 22, 1090: ,virginitatis decus”.

106 Por. Epistula 22, PL 22, 394-425, Czuj I 110-162; Epistula 49, 18, PL 22,Czuj I 302.

107 Por. Epistula 52, 17, PL 22, 539, Czuj I 348: „oszkalowano mój list o dziewictwie, który dla świątobliwej Eustochium w Rzymie napisałem".

${ }^{108}$ Por. Epistula 32, PL 22, 445-446, CSEL 54, 249-251, Czuj I 190-191: „Male kształtem, lecz wielkie miłością są dary, które otrzymałem od Dziewicy: naramienniki, list i gołębie otrzymałem i kosz napełniony czereśniami bardzo pięknymi".

${ }^{109}$ Por. Epistula 108, 6, PL 22, 881, Czuj II 419: „Z milości ku Bogu [Paula] wzgardzila milością ku dzjeciom, i tylko w jednej Eustochium miała pociechę, która jej towarzyszyła w podróży i w wykonywaniu zamiaru".

110 Epistula 66, 13, PL 22, 646, Czuj II 93.

111 Por. Commentarii in Isaiam, PL 24, 17-678.

112 Por. Commentarii in Ezechielem, PL 25, 15-490. 
rzy biblijnych ${ }^{113}$, w których raz po raz nazywał ją „dziewicą Chrystusa” lub „córka”. Wzbudzal w niej i podsycal zapał do lektury Pisma św. (lectio divina). Przełożył również dla niej na łacinę Regułę św. Pachomiusza. Gdy zaś w latach 402-403 jej matka Paula ciężko chorowała, ona siedziała przy jej łóżku i gorliwie ją pielęgnowała ${ }^{14}$. Mimo iż matka pozostawiła ją w długach, ciężko jej było rozstać się ze zmarłą ${ }^{15}$. Po jej śmierci przejęła opiekę i zarząd $(404$ r.) nad założonym przez nią ponad 50-osobowym żeńskim klasztorem, kontynuując nadal jej dzieło. Wówczas to otoczonej opinią świętości złożyl jej wizytę Paladiusz, zwiedzający klasztory Palestyny ${ }^{116}$. Eustochium zmarła w 419 r., ale nie znamy dokładnie dnia jej śmierci ${ }^{117}$. Pochowano ją obok matki w grocie betlejemskiej. Jej śmierć napełniła wielkim smutkiem św. Hieronima, a nawet wpłynęła na dalsze jego życie, które zakończył w rok po niej:

„Bardzo mnie zasmuciło nagłe zaśnięcie świętej i czcigodnej dziewicy Chrystusowej Eustochium i niemal zmieniło sposób mego życia, a poza tym wielu moich zamiarów nie mogę wykonać i żar umysłu wygasa pod wpływem starczego niedołęstwa"118.

Nic dziwnego, bo byla ona jego najbliższą i najwierniejszą uczennicą, jak również inspiratorką jego naukowej biblijnej działalności.

Druga także, najstarsza córka Pauli - Blezyla ${ }^{119}$, była mocno związana $z$ żeńskim klubem na Awentynie, dokąd $z$ matką i siostrami uczęszczała na konferencje Hieronima ${ }^{120}$. Początkowo żyła wygodnie i dostatnio w arystokra-

${ }^{113}$ Por. Commentarii in Naum, In Micheam, In Sofronium, In Aggaeam, In Ecclesiasten, Ad Galatas, Ad Ephesios, Ad Titum, Ad Philemonem.

114 Por. Epistula 108, 28, PL 22, 904, Czuj II 449, zob. wyżej nota 88.

115 Epistula 108, 30-31, PL 22, 905, Czuj II 451.

116 Por. Palladius, Historia Lausiaca 41, ŹM 12, 187: „Córką Pauli jest Eustochium, która do dziś prowadzi życie ascetyczne w Betlejem. Jej nie spotkałem osobiście, ale słyszałem, że wyróżnia się ona cnotą i kieruje wspólnotą pięćdziesięciu dziewic".

117 Martyrologia podają różne dni jej śmierci: 20 lub 28 września, 20 lutego, 2 marca i 2 listopada. Martyrologium Rzymskie - 28 września, thum. P. Turbak, s. 282: „W Betlejem Judzkim św. Eustochii, panny. Z Paula, świętą matką swoją, przybyla z Rzymu do Palestyny i żyła z innymi pannami przy żłóbku Pana, skąd bogata w zasługi odeszła do nieba $(\uparrow 419) "$.

${ }^{118}$ Epistula 151, 2, CSEL 56, 364, Czuj III 478; zob. Epistula 153, CSEL 56, 366, Czuj III 480; Epistula 143, 2, CSEL 56, 293, Czuj III 413: „Od tego czasu tak cierpiałem, czy to z powodu spadających na mnie chorób, czy to z powodu zaśnięcia świętej i czcigodnej córki Eustochium”.

119 Por. Listy sw. Hieronima: Epistula 22, 15, PL 22, 403, Czuj I 125; Epistulae 38-39, PL 22, 463-473, Czuj I 222-239; Penna, S. Gerolamo, s. 87-88 i 108-109, 136, 148; Jenal, Italia ascetica, s. 4750; Vies des Saints, I, Paris 1935, 437; F. Cavallera, Saint Jérôme, Paris 1922, 102-104; R. Genier, SaintePaule, Paris 1917, 70-77; Mirri, La dolcezza nella lotta, s. 113-116; Catholicisme II 87 (G. Bardy); BS III 207-208 (G.B. Proja); DHGE IX 187 (F. O'Briain); LThK ${ }^{2}$ II 530 (A.P. Frutaz); LThK ${ }^{3}$ II 526 (R. Pillinger); PLRE I 162; DPAC I 546 (U. Dionisi).

${ }^{120}$ Por. Epistula 30, 14, PL 22, 444, Czuj I 189: „Pozdrów [Paulo] Blezylę i Eustochium, uczennice moje (Tirunculae nostrae)". 
tycznym domu. W dwudziestym roku życia wyszła za mąż za brata patrycjuszki Furii $^{121}$, lecz zaledwie po 7 miesiącach małżeństwa owdowiała ${ }^{122}$. Wkrótce po śmierci męża ciężko zachorowała, będąc nawet bliska zgonu, ale gorące modlitwy jej samej, rodziny i Hieronima, pomogły jej powrócić do zdrowia ${ }^{123}$. Odzyskawszy częściowo zdrowie, prawdopodobnie pod wpływem Księgi Eklezjastesa, którą jej czytał po hebrajsku i komentował Hieronim, stwierdzający: ,jestem jej ojcem wedle ducha, którym karmił ją milością"124, zerwała ze światem, nawróciła się i zapragnęła wyższej doskonałości. Porzuciła swoje stroje i ozdoby, przybrała skromne odzienie i poświęciła się lekturze i kontemplacji Pisma św., zwlaszcza Proroków i Ewangelii oraz modlitwie i śpiewaniu Psalmów. Pomagała jej w tym dobra znajomość języka greckiego i hebrajskiego. Ona również stawiała przed Hieronimem problemy egzegezy biblijnej, domagając się od niego przekładu na język łaciński obszernych Orygenesowych komentarzy do Ewangelii Mateusza, Łukasza i Jana ${ }^{125}$. Choroba jednak postępowała i po zaledwie 3 miesiącach takiego ascetycznego życia, zmarła jesienią 383 roku. Ostatnimi jej słowami była skarga, że nie zdążyła zrealizować wszystkich swoich zamierzeń. Urządzono jej wspaniały arystokratyczny pogrzeb, $\mathrm{z}$ czego zapewne, jak sugeruje Hieronim, nie była w zaświatach zadowolona ${ }^{126}$.

Po stracie swej najstarszej córki Paula popadła w rozpacz i Hieronim skierowal do niej wzruszający list (39) konsolacyjny ${ }^{127}$, w którym pocieszal ja i przypominał, że jej córka zdobywszy w tak krótkim czasie wiele cnót moralnych i intelektualnych, jest obecnie szczęśliwa w niebie ${ }^{128}$. Przyrzekal równiez, że nigdy o niej nie zapomni i sławil ją będzie w swoich pismach, w których obok Pauli i Eustochium będzie żyć przez wieki ${ }^{129}$. Tego rodzaju deklaracje i zapew-

121 Por. Epistula 54, 2, PL 22, 550, Czuj I 366: „pomijam też Blezylę, która poszedłszy za mężem swym, bratem twoim, w krótkim życiu przeżyla czasów wiele".

122 Epistula 22, 15, PL 22, 403, Czuj I 125.

123 Epistula 38, 2, PL 22, 463, Czuj 1222.

124 Epistula 39, 2, PL 22, 464, Czuj I 227.

125 Por. Origenes, Homiliae in Lucam. Prologus, SCh 87, 94, PSP 36, 31: „Niegdyś w Rzymie świątobliwa Blezyla usilnie domagała się ode mnie, abym przełożył na nasz język dwadzieścia szesć ksiąg Orygenesowego Komentarza do Ewangelii Mateusza, pięć ksiąg Komentarza do Łukasza i trzydzieści dwie księgi Komentarza do Jana".

126 Por. Epistula 38, 4 i 39, 1, PL 22, 464-466, Czuj I 224-227.

127 Por. Epistula 39, PL 22, 465-473, Czuj I 226-239; Epistula 108, 4, PL 22, 880, Czuj II 417: „Miała pięcioro dzieci: Blezylę, po której śmierci pocieszałem ją w Rzymie”. Epistula 77, 1, PL 22, 690, Czuj II 158: „Wiele lat upłynęło od chwili, gdy pocieszałem czcigodną Paulę po zaśnięciu Blezyli".

${ }_{128}$ Por. Epistula 39, 2-3, PL 22, 466-468.

129 Por. Epistula 39, 7, PL 22, 473, Czuj I 239: „Dopóki używam tego życia, slubuję, przyrzekam, obiecuję: będę ją sławil, będę jej poświęcał prace moje, dla niej trudzić się będą moje zdolności. Nie będzie żadnej stronicy, która by nie brzmiała Blezylą. Dokądkolwiek dojdą pomniki mowy mojej, ona z dziełkami mymi podróżować będzie. Ją to, w myśli mojej obecna, czytać będą 
nienia Hieronima były tym bardziej uzasadnione, że podczas pogrzebu Blezyli wybuchły w Rzymie zamieszki skierowane głównie przeciw niemu za zalecanie jej zbyt surowej ascezy, będącej jakoby powodem jej śmierci. Była to jedna z przyczyn, która go zmusiła do opuszczenia Rzymu ${ }^{130}$.

O pozostałych trojgu dzieciach Pauli znamy o wiele mniej szczegółów ${ }^{131}$, choć można przypuszczać, że matka prowadzała je również ze swymi dwiema, omówionymi wyżej, córkami na awentyńskie konferencje św. Hieronima. One więc mogły także stykać się $\mathrm{z}$ ascetyczno-intelektualną atmosferą tego miejsca. Druga z kolei córka Pauli - Paulina ${ }^{132}$, wyszła za mąż za bogatego, wywodzącego się z patrycjuszowskiego rodu „prawnuka konsulów i chlubę rodu Furiuszów" - Pammachiusza. ${ }^{133}$ Nie doczekawszy się potomstwa, zapewne pod wpływem Hieronima, postanowili żyć w czystości. ${ }^{134}$ Po połączeniu swoich ogromnych majątków zdecydowali, by swym bogactwem dzielić się z ubogimi. Po śmierci Pauliny Pammachiusz, wierny pamięci żony i kontynuator jej dzieła, cały majątek przekazał na cele dobroczynne, umożliwiając egzystencję wielu potrzebującym. Pomoc i opiekę znaleźli u niego nie tylko ludzie śmiertelnie chorzy, ale także kalecy, głuchoniemi i ociemniali ${ }^{135}$. Pammachiusz, którego Hieronim nazywa swoim „najdroższym bratem" ${ }^{136}$, po śmierci żony jeszcze bardziej zmienił swój sposób życia - ku zdziwieniu i śmiechowi arystokracji rzymskiej, przywdział tunikę mnicha i oddał się bez reszty ubogim ${ }^{137}$. Wspólnie

dziewice, wdowy, mnisi kapłani. Krótkie życie wieczna pamięć wynagrodzi. Ta, która z Chrystusem żyje w niebiosach, także na ustach ludzi żyć będzie. Przejdzie i niniejszy wiek, nastąpią potem wieki przyszłe, które bez miłości, bez zawiści sądzić będą; między imionami Pauli i Eustochium będzie wymieniana. Nigdy nie umrze w mych ksiązkach".

130 Por. Penna, S. Gerolamo, s. 108-109.

131 Por. Epistula 108, 4, PL 22, 880, Czuj II 417.

132 Por. Epistula 66 (do Pammachiusza po śmierci Pauliny), PL 22, 639-647, Czuj II 81-94; Episiulae 77, 10 i 108, 4; PL 22, 696 i 880; PLRE I 675.

133 Por. Epistula 66, 6, PL 22, 642, Czuj II 86.

134 Por. Epistula 66, 3, PL 22, 640, Czuj II 83-84.

135 Por. Epistula 66, 5, PL 22, 641, Czuj II 84-85: „Błyszczące klejnoty, które przedtem zdobily jej szyję i twarz, karmią głodnych; jedwabne szaty i złoto przerobione na miękkie welniane okrycia shużą do ochrony przed zimnem, a nie do uzewnętrzniania próżności; to, co było niegdyś narzędziem rozkoszy, sluży obecnie cnocie. Ten ślepy, wyciągający rękę przed siebie i wołający często tam, gdzie nikt go usłyszeć nie może, jest spadkobiercą Pauliny, a współdziedzicem Pammachiusza; tamtego z obciętymi nogami, który całym ciałem wlecze się po ziemi, podtrzymuje ręka młodej dziewczyny. Te drzwi, które dawniej wyrzucały tłumy klientów teraz oblegane są przez nędzarzy; jeden, nabrzmiały od puchliny wodnej, walczy ze śmiercią; drugi, bez języka i niemy, nie ma nawet narządu, którym by mógł prosić, lecz błaganie jego jest tym silniejsze, że błagać nie może; ten, ułomny od maleńkiego nie dla siebie żebrze o jałmużnę, ów, zgniły od choroby królewskiej, przeżył wlasne ciało".

${ }_{137}^{136}$ Por. Epistula 66, 12, PL 22, 646, Czuj II 92.

137 Por. Epistula 66, 4, PL 22, 640, Czuj II 84: „Nam po zaśnięciu Pauliny zrodził Kośció1 Pammachiusza, mnicha pogrobowca, patrycjusza przez szlachectwo ojca i żony, bogatego przez jałmużny, wzniosłego przez pokorę [...]. W naszych czasach Rzym posiada to, czego swiat przedtem 
z Fabiolą w 398 r. założył dla podróżnych w Ostii pierwsze chrześcijańskie ksenodochium ${ }^{138}$, w którym sam usługiwał. Uległ zapewne atmosferze awentyńskiego ośrodka Marceli, dokąd prawdopodobnie uczęszczal najpierw z narzeczoną, a potem żoną Pauliną. Ją to po śmierci wychwalał św. Hieronim. w pełnym retoryki liście, skierowanym do owdowiałego męża ${ }^{139}$.

O kolejnej córce Pauli - Rufinie wiemy, że była „panną na wydaniu i milczała prosząc tylko łzami, by zaczekała do jej ślubu" ${ }^{\text {"140 }}$, kiedy matka opuszczała w $386 \mathrm{r}$. Rzym, udając się do Palestyny. Zapewne razem z matką uczestniczyła w konferencjach głoszonych przez św. Hieronima na Awentynie. Nic jednak więcej o niej nie wiemy, oprócz tego, że wiele chorowała i zmarła w młodym wieku, a ,jej przedwczesny zgon wstrząsnął do głębi pobożną duszę matki"141.

$\mathrm{Z}$ rodziną Pauli, a tym samym $\mathrm{z}$ żeńskim towarzystwem awentyńskim związana była bratowa Blezyli - Furia ${ }^{142}$, córka byłego konsula oraz Tycjany, pochodząca ze starych rzymskich rodów Furiuszów i Grakchów. ${ }^{143}$. Po śmierci męża Probusa w 394 r., również konsula ${ }^{144}$, zmuszana była przez ojca do powtórnego małżeństwa, przed czym się wzbraniała, ulegając panującej wówczas w Rzymie chrześcijańskiej ascezie. O pomoc poprosiła przebywającego w Betlejem Hieronima, aby jej „odpisal, a raczej napisał, w jaki sposób ma żyć i koronę wdowieństwa w postaci nietkniętej czystości zachować" ${ }^{145}$. Ten w odpowiedzi, choć poza listami nie znal jej osobiście ${ }^{146}$, skierowal do niej długi list - traktat o zachowaniu wdowieństwa ${ }^{147}$, w którym oprócz stosowania róż-

nie znał. Dawniej mądrzy, możni i szlachetnego rodu rzadko byli chrześcijanami; teraz wielu jest mnichów mądrych, możnych, szlachetnych. Od nich wszystkich mój Pammachiusz jest mądrzejszy, możniejszy i szlachetniejszy; wielki wśród wielkich, pierwszy wśród pierwszych, naczelny wódz mnichów [...]".

138 Por. Epistula 66, 11, PL 22, 645, Czuj II 90-91: „Słyszę, że w porcie rzymskim założyłé́ gospodę dla podróżnych”; Epistula 77, 10, PL 22, 697, Czuj II 168-169; S. Longosz, Ksenodochiumhospicjum wczesnochrześcijańskie, VoxP 16 (1996) z. 30-31, szczególnie 309-311.

${ }^{139}$ Por. Epistula 66, 1, PL 22, 639, Czuj II 82: „Któż by mógł spokojnymi patrzeć oczyma, jak więdnie przedwcześnie ścięta, zaledwie rodząca róża, pączek, który się jeszcze nie otworzyl i nie rozwinął całego przepychu czerwieniejących płatków. Zniszczona została najkosztowniejsza perła, starty został cenny zielony szmaragd. Dopiero w chorobie okazuje się, jakim szczęściem jest zdrowie. Dobro, któreśmy posiadali, więcej cenimy, gdy je stracimy".

140 Epistula 108, 6, PL 22, 881, Czuj II 419; zob. PLRE I 773.

141 Epistula 108, 4 i 19, PL 22, 880 i 897, Czuj II 417 i 437.

142 Por. Epistula 54, 2, PL 22, 550, Czuj I 366.

143 Por. Epistula 54, 1 i 4 i 6, PL 22, 550 i 551 i 552, Czuj I 366 i 368 i 370.

144 Por. Epistula 123, 18, PL 22, 1059, Czuj III 234: „Przeczytaj listy do Furii i do Salwiny. z których pierwsza jest synową byłego konsula Probusa, druga córką Gildona zarządcy Afryki".

145 Epistula 54, 1, PL 22, 550, Czuj I 366.

146 Por. tamże 54, 3, PL 22, 550, Czuj I 367: „Poza listami nie znamy się wzajemnie, a tam, gdzie nie ma żadnej bliskiej znajomości, jedyną pobudka jest pobożność".

${ }^{147}$ Por. Epistula 54, PL 22, 550-560, Czuj I 366-383. 
nych umartwień i środków ascetycznych, zalecał jej m.in. codzienną lekturę Pisma św. i innych naukowych książek teologicznych:

„Kiedy jesz, pomyśl zaraz, ze masz się modlić i czytać. Miej ustaloną do przeczytania liczbę wierszy z Pisma św.; tę pracę codzienną oddaj Panu swemu i nie wcześniej układaj członki na spoczynek, aż kosz serca twego tą napełnisz przędzą. Po Piśmie św. czytaj rozprawy ludzi uczonych, oczywiście tych, których wiara jest znana. Nie masz potrzeby szukać złota w błocie [...]. Upodobanie w naszyjnikach, drogich kamieniach i jedwabnych szatach zamień na znajomość Pisma świętego" ${ }^{\prime 148}$.

„Uczona” więc atmosfera awentyńskiego klubu nadal promieniowała, kierowana ciągle przez przebywającego w Betlejem mistrza.

Klub awentyński był chyba pierwszą chrześcijańską formacją intelektualną kobiet, do której przyczynił się owocnie przede wszystkim św. Hieronim. To jego biblijne konferencje i objaśnianie Pisma św., oparte na oryginalnym tekście hebrajskim i greckim, zmuszały nie tylko jego słuchaczki do pogłębionego, systematycznego studium Pisma św., uczenia się języków biblijnych, codziennej medytacji Biblii oraz refleksji i stawiania problemów biblijnych, ale również jego samego mobilizowały do pisania komentarzy biblijnych i analitycznego studium Pisma świętego. Lektura Pisma św., zwana lectio divina, stała nie tylko u podstaw tworzenia się inteligencji chrześcijańskiej wśród rzymskich arystokratek $^{149}$, lecz także podejmowania przez nie systematycznej ascezy. Ślubując zazwyczaj czystość i dziewictwo oraz podejmując skromny styl życia, mieszkały one we własnych domach. Nie tworzyły więc klasztoru ani formalnej wspólnoty, nie miały wspólnej reguły ani ściśle określonych zasad ascezy. Ich jednak sposób życia stanowił fundament pod rozwój żeńskiego życia zakonnego w Wiecznym Mieście ${ }^{150}$.

${ }^{148}$ Epistula 54, 11, PL 22, 556, Czuj I 375.

${ }^{149}$ Por. Ph. Rousseau, "Learned women” and the development of a Christian culture in late antiquity, ,Symbolae Osloenses” 70 (1995) 116-147, szczególnie 131-143; A. Yarbrough, Christianization in the Fourth Century: the example of Roman women, „Church History” 45 (1976) 149-165; Y. Bodin, Jérôme et les laïcs, REAug 15 (1969) 133-147; D. Gorce, La "lectio divina" nell'ambiente di S. Girolamo. Bologna 1991; L. Laurita, Insegnamenti ascetici nelle lettere di S. Girolamo, Nocera Superiore 1967, 4-20 (La „lectio divina” e il culto della Scrittura).

${ }^{150}$ Por. G.D. Gordini, Origine e sviluppo del monachesimo a Roma, „Gregorianum” 37 (1956) 220-260. 


\section{FRAUENKREIS DER CHRISTLICHEN INTELLIGENZ AM RÖMISCHEN AVENTIN IM IV. JAHRHUNDERT}

\section{(Zusammenfassung)}

Aventinischer Kreis der adligen Frauen im IV. Jahrhundert war wohl die erste christliche intellektuelle und feministische Gruppe in Rom. $\mathrm{Zu}$ diesem Kreis gehörten: Marcella und ihre Mutter Albina, Asella, Melania, Fabiolla, Sophrania, Furia, Principia, Lea, Paula und ihre vier Töchter - Blesilla, Eustochium, Rufina und Paulina und auch ihre Schwiegertochter Leta, noch Marcellina - die Schwester des hl. Ambrosius und Irena - die Schwester des Papstes Damasus. Zur Entwicklung dieses Kreises hat der hl. Hieronymus durch biblische Konferenzen, gegründet auch originellem hebräischem und griechischem Text, wesentlich beigetragen. Sie zwangen die Beteiligten zur vertieften Studie, zum Lesen und zur Meditation der Heiligen Schrift, lectio divina genannt, und veranlassten sie zur Praktik der systematischen Aszese, die den Grund zur Entwicklung des Frauenordenslebens in der Ewigen Stadt war. 